IZA DP No. 4555

The Economic Diversity of Immigration Across the United States

Rachel M. Friedberg

David A. Jaeger

November 2009 


\title{
The Economic Diversity of Immigration Across the United States
}

\author{
Rachel M. Friedberg \\ Brown University \\ and NBER \\ David A. Jaeger \\ University of Cologne, \\ CUNY Graduate Center and IZA
}

\section{Discussion Paper No. 4555 \\ November 2009}

\author{
IZA \\ P.O. Box 7240 \\ 53072 Bonn \\ Germany \\ Phone: +49-228-3894-0 \\ Fax: +49-228-3894-180 \\ E-mail: iza@iza.org
}

\begin{abstract}
Any opinions expressed here are those of the author(s) and not those of IZA. Research published in this series may include views on policy, but the institute itself takes no institutional policy positions.

The Institute for the Study of Labor (IZA) in Bonn is a local and virtual international research center and a place of communication between science, politics and business. IZA is an independent nonprofit organization supported by Deutsche Post Foundation. The center is associated with the University of Bonn and offers a stimulating research environment through its international network, workshops and conferences, data service, project support, research visits and doctoral program. IZA engages in (i) original and internationally competitive research in all fields of labor economics, (ii) development of policy concepts, and (iii) dissemination of research results and concepts to the interested public.
\end{abstract}

IZA Discussion Papers often represent preliminary work and are circulated to encourage discussion. Citation of such a paper should account for its provisional character. A revised version may be available directly from the author. 
IZA Discussion Paper No. 4555

November 2009

\section{ABSTRACT}

\section{The Economic Diversity of Immigration Across the United States}

While it is well known that some areas of the United States receive more immigrants than others, less is understood about the extent to which the character of immigration varies as well. There is much broader geographic variation in the skill and demographic composition of immigrants than natives, with important implications for their economic effects. This paper provides a new perspective by focusing on heterogeneity in outcomes such as the share of population growth due to immigration, the presence of immigrant children in schools, and the effect of immigration on the age, sex, language, and educational composition of the local population and workforce.

JEL Classification: J61, J68, J4

Keywords: immigration, local labor markets, immigrant children, language

Corresponding author:

David A. Jaeger

Center for Macroeconomic Research

WiSo Building 717

University of Cologne

Albertus-Magnus-Platz

D-50923 Köln

Germany

E-mail: jaegerd@uni-koeln.de

\footnotetext{
* The authors thank the Brookings Institution for financial support and Audrey Singer for helpful comments. Spencer Amdur and Konstantin Kashin provided excellent research assistance.
} 


\section{Introduction}

Immigration is a perennially divisive political issue in the United States. Despite a clear consensus that the current system is broken, passing legislation to reform it has proved an elusive goal to successive presidential administrations. With roughly half of new arrivals into the country now entering illegally and the number of undocumented immigrants having reached 12 million, overcoming the obstacles to passing comprehensive immigration reform legislation is more urgent than ever. ${ }^{1}$

One of the intriguing aspects of immigration policy is that, although it is set nationally, many of its effects are felt most strongly at the state and local levels. Moreover, while many of the benefits of immigration accrue to the United States as a whole, the costs tend to be more geographically concentrated. Some areas receive many more immigrants than others. Furthermore, there is much wider geographic variation in the demographic and skill profile of immigrants than there is among natives. While the typical immigrant in cities like Fresno, California or McAllen, Texas is a Mexican high-school dropout with limited English proficiency, in other cities like Edison, New Jersey, the typical immigrant is an Indian software engineer. Likewise, while immigrants' children make up only $9 \%$ of schoolchildren in Baltimore, they comprise the majority in Los Angeles. As a result, the character and economic impact of immigration differs dramatically from place to place.

This paper offers a look at some of the most salient ways in which immigration is reshaping the landscape of local economies, workforces, municipal budgets, and schools. In contrast to most of the research on the economics of immigration, which focuses on its aggregate effects, the emphasis here is on the wide local variation that underlies the national statistics. Analyzing the diversity of local experiences, not only in terms of the size and growth of the immigrant population, but also in terms of its demographic and economic

\footnotetext{
${ }^{1}$ Passel and Cohn (2009) estimate the undocumented immigrant population in the U.S. to be 11.9 million in 2008.
} 
characteristics, provides a different perspective on immigration, one that is often missing from the national debate.

This study focuses on five key aspects of the economics of immigration in U.S. metropolitan areas:

- First, immigration is the sole or primary source of population growth in many metropolitan areas, primarily those with slow native population growth, and not those with rapid immigrant population growth.

- Second, a substantial fraction of schoolchildren in most metros are the children of immigrants. Nationally, virtually all of the growth in the school-age population is attributable to the native-born children of immigrants, with local variation again tending to reflect more about native than immigrant demographics.

- Third, immigration raises the ratio of men to women, particularly in certain areas. However, the reverse is actually true in others. Immigration generally lowers the average age of the population, though its overall effect on the age structure varies from place to place.

- Fourth, while immigrants tend to have lower educational attainment, Englishlanguage proficiency, and earnings than natives, there is enormous geographic variation in the skills they bring to the labor force.

- Fifth, despite higher poverty rates, immigrants have lower rates of welfare receipt than natives. Before the recent deep recession, they also had lower rates of unemployment, particularly in certain types of places.

In the next section, we present our data and methodology, including our partitioning of metropolitan areas into different groups, based upon the characteristics of their immigrant populations. The subsequent section presents our five key findings in detail, and the final section concludes by offering some policy implications. 


\section{Methods and "Metrotypes"}

Throughout this study, we define immigrants to be people born abroad who were not U.S. citizens at birth, i.e., non-citizens and naturalized citizens. In order to capture fully the effect of immigration on demographic trends, we widen our focus to include immigrants and their children-- including those born in the United States- since these children would not be in the country had their parents not immigrated. ${ }^{2}$ The analysis is conducted using the Public Use Microdata of the U.S. Census of 2000 and the American Communities Survey of $2007 .^{3}$ In order to include the full reach of the local economy and labor market, the unit of observation we use is a Metropolitan Statistical Area (MSA). ${ }^{4}$

We focus on metropolitan areas with over 150,000 immigrants. ${ }^{5}$ There were 42 such metros in 2007, including places where a large fraction of the population was foreign-born, as well as major metropolitan areas where immigrants were less dominant. These 42 metros covered $77 \%$ of the foreign-born population and $42 \%$ of the native-born population of the United States in 2007.

We group these metropolitan areas into four categories, or "metrotypes," based upon the characteristics of their local immigrant populations, including their level of education, country of origin, and years since migration. These traits are correlated with economic outcomes such as unemployment rates and earnings, as well as demographic outcomes like

\footnotetext{
${ }^{2}$ We classify children according to their parentage, rather than their birthplace. Children are categorized as being "children of immigrants" if both parents are foreign-born, if their single resident parent is foreign-born, or if the head of household is foreign-born and there are no parents present. Children with at least one native parent are categorized as "children of natives." Children born abroad not to U.S. citizens are, of course, also treated as immigrants. U.S.-born children of immigrants who were over the age of 18 at the time of the Census are treated as natives, because the Census does not collect information on the nativity of the parents of those living outside of their parents' household.

${ }^{3}$ There are 2,994,665 observations in the 2007 ACS microdata.

${ }^{4}$ We are grateful to Alec Friedhoff and Audrey Singer for providing us with a crosswalk to match the MSA geography between the 2000 Census and the 2007 American Communities Survey. We use the 2005 Office of Management and Budget definitions of MSAs, with the exception of combining Raleigh and Durham into one area. The precise definitions can be found at http://www.whitehouse.gov/omb/bulletins/fy2006/b06-01_rev_2.pdf.

${ }^{5}$ Appendix Table 1 lists the 42 metropolitan areas in our study, along with their immigrant and native population statistics for 2000 and 2007.
} 
the age structure, ratio of men to women, and number of children, all of which have important implications for immigration's local impact. ${ }^{6}$

Below are the four metrotypes we will employ for the rest of the paper:

New Immigrant Metros are the metropolitan areas with the most recently arrived immigrants. This group is comprised of the nine places where immigrants who arrived within the past decade make up the greatest share of the local immigrant population. ${ }^{7}$ The New Immigrant Metros in our study include Atlanta, Austin, Charlotte, Dallas, Denver, Minneapolis, Orlando, Phoenix, and Salt Lake City.

Hispanic Immigrant Metros are those where the great majority of immigrants are Hispanic. ${ }^{8}$ These 16 places include Bakersfield, El Paso, Fresno, Houston, Las Vegas, Los Angeles, McAllen, Miami, Oxnard, Riverside, Salinas, San Antonio, San Diego, Stockton, Tucson, and Visalia

Educated Immigrant Metros are metropolitan areas in which over one-third of immigrants are college graduates. There are nine such metros. They are Baltimore, Boston, Detroit, Philadelphia, Raleigh-Durham, San Francisco, San Jose, Seattle, and Washington.

Balanced Immigrant Metros are the eight metropolitan areas whose immigrants represent a mix of characteristics, in terms of their education, recency, and origin. These eight places are Bridgeport, Chicago, Hartford, New York, Portland, Providence, Sacramento, and Tampa.

Metropolitan areas that meet the criteria of more than one category are grouped with the places they most closely resemble along other dimensions. While any such

\footnotetext{
${ }^{6}$ By stratifying on the basis of the kind of immigrants to be found in a particular metro, our typology both differs from and complements other ways of classifying metros, most notably that of Singer (2004), which focuses on the timing of a metropolitan area's role as an immigrant gateway, sorting metros according to the predominant time period of local immigrant inflows.

${ }^{7}$ The cutoff is at least $40.5 \%$ of the immigrant population having arrived in the prior decade.

${ }^{8}$ These are places where the immigrant share is greater than $58 \%$.
} 
classification is somewhat arbitrary, the typology defined here turns out to capture important similarities across metropolitan areas, enabling us to draw general conclusions about the ways in which immigrants' outcomes and impacts vary across different types of locations.

\section{Results}

\section{A. Immigration and Population Growth}

One in eight people in the United States was born abroad, and over a quarter of population growth in the United States is now due to the arrival of new immigrants. Taking account of the native-born children of immigrants, close to one-half of population growth in the 2000s has been due to the entry of immigrants and the birth of their children. ${ }^{9}$ This represents something of a decline, relative to the 1990 s, when the share was $61 \%$. Still, in the period $2000-2007$, while the native-born population grew by just $4.4 \%$, the immigrant population, inclusive of children, increased by one-quarter. Immigrants and their children therefore make up an increasing fraction of the U.S. population, rising from $10.8 \%$ in 1990 , to $14.1 \%$ in 2000 , to $16.2 \%$ in 2007 . Over one-third of immigrants arrived within the last decade, and these new immigrants comprise $6 \%$ of the overall U.S. population.

The metropolitan areas with the largest immigrant populations are still traditional immigrant cities like New York, Los Angeles, Miami, and Chicago. However, the geographic distribution of immigrants has been steadily shifting away from these cities since the 1990s. ${ }^{10}$ New destinations like Raleigh-Durham, Charlotte, Phoenix, Atlanta, and Orlando have seen explosive growth in their immigrant populations, with around $70 \%$ more immigrants in 2007 than 2000.

There is substantial variation across metropolitan areas in the share of population growth attributable to immigrants and their children. Figure 1 shows that share during the

\footnotetext{
${ }_{10}^{9}$ For the rest of the analysis, the children of immigrants will be counted in the immigrant population. 10 See Singer (2004), and Hernández-León and Zúñiga (2005), Card and Lewis (2007), and Massey (2008) for analyses of this phenomenon.
} 
period 2000-2007 for each of the four metrotypes defined above, computed as the population-weighted average across the metropolitan areas included within each metrotype.

Figure 1: Share of Population Growth Due to Immigration 2000-2007

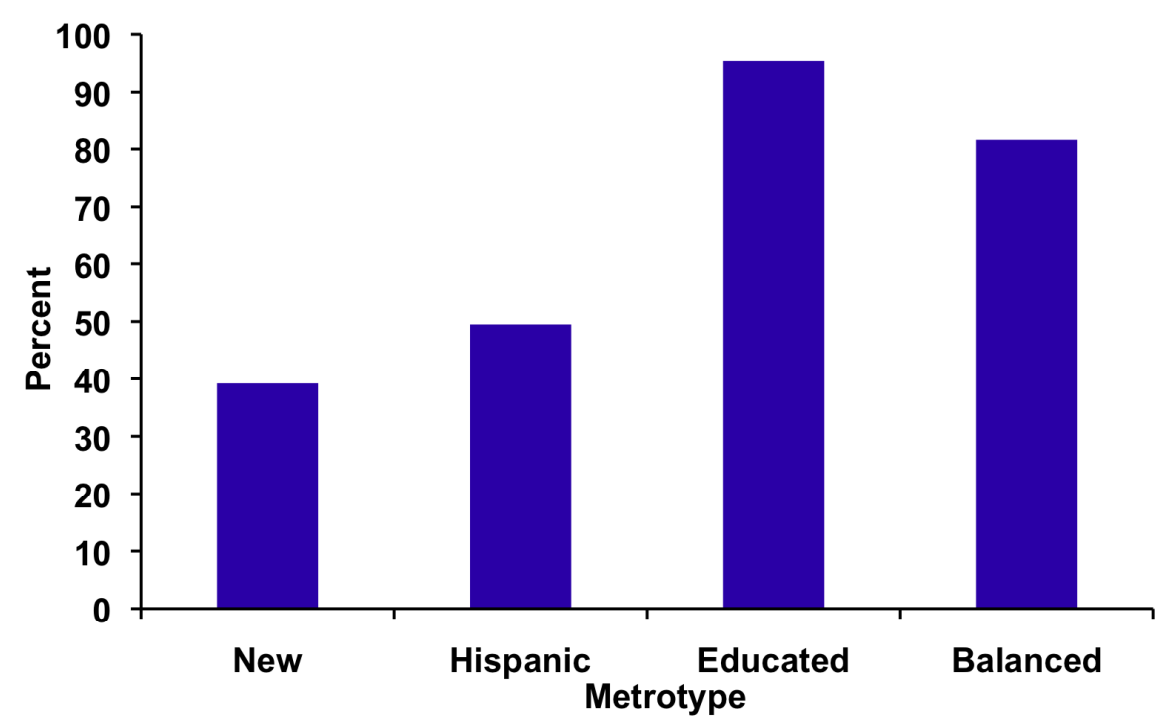

Source: Authors' calculations from 2000 IPUMS and 2007 ACS data. See Appendix Table 1. Note: Immigration includes the foreign-born and their children. See text for definition.

Immigration is the only source of population growth in most Educated Metros and the primary source in most Balanced Metros. Immigration supplies half of population growth in Hispanic Metros. It is less important in New Metros, where both native and immigrant population growth are strongest.

Though growth in the immigrant population has been highest in the New Metros, these areas have seen substantial increases in their native populations as well, with the result that immigration actually plays a relatively minor role in population growth in these places $\left(39 \%\right.$ of it), compared to elsewhere in the country. ${ }^{11}$ In contrast, immigration

\footnotetext{
${ }^{11}$ Note that these numbers do not capture any causal link between immigrant and native population growth, but merely compute the share of observed net population growth that is accounted for by growth in the local immigrant population.
} 
accounts for virtually all of the population growth that has occurred in Educated Metros since 2000 , compensating for declining native populations in the majority of them -- places like San Jose, San Francisco, Detroit, and Boston. Shrinking native populations in some Balanced Metros, including Bridgeport, New York City, and Providence, ${ }^{12}$ have been accompanied by strong immigrant population growth in others, with the result that immigration has contributed the majority (82\%) of local population growth in Balanced Metros overall. Finally, in Hispanic Metros -- places like Los Angeles and San Diego -- half of population growth has been due to immigration, including natural increase in the settled immigrant population.

The share of overall population increase due to immigration ranges from a low of $22 \%$ in San Antonio to a high of $389 \%$ in Detroit. Clearly, immigration has a major impact on the relative size and growth rates of metropolitan areas across the United States, with implications for a host of outcomes -- economic, social, and political --both at the metro level, as well as in terms of their relative standing at the national level.

\section{B. Size and Growth of the School-Age Population}

One of the key concerns of state and local policymakers regarding immigration is the burden that immigrants' children may place on local school systems, through increased enrollments, as well as through the cost of providing extra services, such as ESL or Spanish-language instruction. While immigrants are $15.6 \%$ of the adult population of the United States, their children make up $17.6 \%$ of the school-age population. Furthermore, almost one in five preschoolers in the United States is the child of immigrants, with the fraction reaching one-half in many Hispanic Metros, such as San Jose and Los Angeles. In

\footnotetext{
${ }^{12}$ Numbers over $100 \%$ reflect overall population growth in the presence of native population decline.
} 
a context of declining numbers of children born to native families in many metropolitan areas, immigration plays a dominant role in the expansion of the school-age population.

There is substantial geographic variation in number of children living in immigrant households, and consequently in the degree to which immigration affects the size and growth of the local school-age population. In Figure 2, we show the composition of the school-age population (defined as those between the ages of 5 and 18, inclusive) broken down into three categories: native-born children of immigrants, native-born children of natives, and immigrant children, i.e., children born abroad. One in eight native-born children in the United States has immigrant parents.

Figure 2: Nativity of School Age Children (2007) and Share of Growth Due to Immigration (2000-2007)

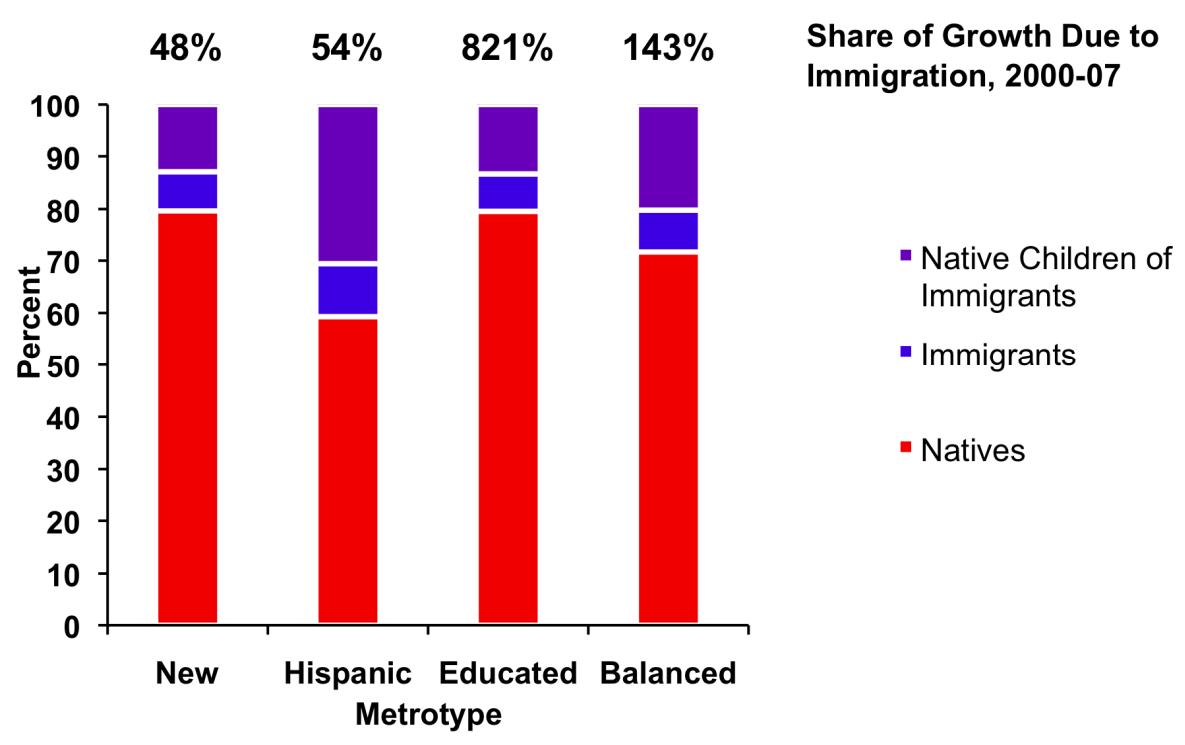

Source: Authors' calculations from 2000 IPUMS and 2007 ACS data. See Appendix Table 2. Note: See text for definition of native children of immigrants and immigrant children.

About $40 \%$ of school age children in Hispanic Metros are the children of immigrants, roughly double the share in New and Educated Metros. All of the growth in the school-age population in Educated and Balanced Metros is attributable to the native-born children of 
immigrants, while about half of the increase in New and Hispanic Metros is due to immigration.

Immigration accounts for the greatest share of the school-age population in Hispanic Metros, where over $40 \%$ of pupils are the children of immigrants. Three-quarters of those children were born in this country, highlighting the significance of considering children's parentage and not just nativity when evaluating data on the effect of immigration on schools. About one-fifth of the schoolchildren in New and Educated Metros are the children of immigrants, with about $1 / 3$ of them born abroad. In Balanced Metros, the native- and foreign-born children of immigrants make up intermediate shares of the school age population $--20 \%$ and $8 \%$ respectively.

The numbers at the top of Figure 2 report the share of growth in the school-age population in 2000-2007 accounted for by the children of immigrants. ${ }^{13}$ Strikingly, the children of immigrants are responsible for all of the growth in the number of schoolchildren in Educated and Balanced Metros. The number of children in native households fell by 1$3 \%$ on average in these metrotypes over this period, and by more than $4 \%$ in places like San Francisco, Seattle, Philadelphia, and Providence.

Immigrants are also responsible for the majority of growth in the school-age population in Hispanic Metros (54\%) and close to half in New Metros (48\%). It is perhaps surprising to find that this share is lowest in New Metros, since these are by far the places of strongest growth in the number of children with immigrant parents. However, the degree to which immigration accounts for expansion in the school-age population turns out to be determined primarily by demographic changes among native families, i.e., changes in the number of children per family, rather than local immigrants.

\footnotetext{
${ }^{13}$ As discussed above, this discussion abstracts from any causal effect of immigration on the behavior of natives, or vice versa, for example, if the entry of immigrant children into an area leads to the outmigration of local natives.
} 
At the national level, practically all of the growth in the school-age population is attributable to the native-born children of immigrants. Whether children from immigrant families account for all or "only" half of growth in the number of schoolchildren in a particular metropolitan area, it is clear that immigration is substantially reshaping the current and future character of schools across the country.

\section{The Demographic Composition of the Population}

Immigration has important effects on the demographic composition of the places in which they settle. It raises the ratio of men to women in most places, particularly in New Metros, but it actually lowers the ratio in one-quarter of them. Immigration also lowers the average age, with the youngest immigrants to be found in New Metros.

The ratio of men to women is fairly constant among natives across the United States. However, there is wide variation in the fraction of recent immigrants who are men, ranging from less than $40 \%$ in El Paso to over $60 \%$ in Raleigh-Durham and Austin. This varying gender mix suggests differences both in the kind of work done by new immigrants in a

particular metro (e.g., construction versus housekeeping) as well as the prevalence of children in immigrant households, as discussed in the previous finding.

Nationally, immigrants of working age are slightly more likely to be male than natives, with male shares of $51.6 \%$ and $49.6 \%$, respectively. This is especially the case among the most recently arrived, $52.8 \%$ of whom are male. In Figure 3, we present the share of the working-age population that is male among natives and immigrants, both recent and overall. The figure illustrates the narrow variation in the male share among natives, ranging from 49.3\% in Educated Metros to $50.1 \%$ in Hispanic Metros. 


\section{Figure 3: Male Share of Working Age Population}

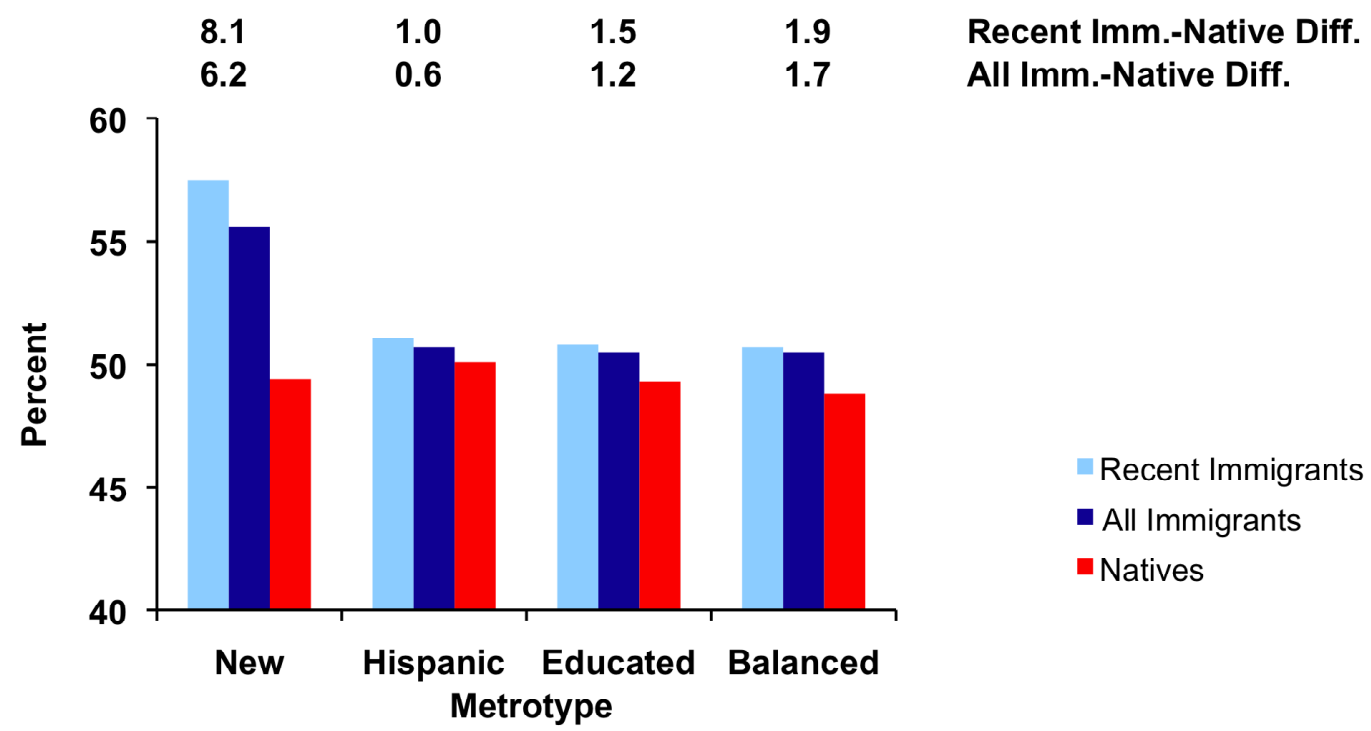

Source: Authors' calculations from 2007 ACS data. See Appendix Table 4. Note: Includes only working-age individuals (age 18-65).

The predominance of men among immigrants is most striking in New Metros, where recent immigrants are more than 8 percentage points more likely to be male than local natives. The fraction male reaches a high of $63 \%$ among immigrants of all vintages in Raleigh-Durham. Immigration raises the ratio of men to women in every New Metro.

On the other hand, immigration actually lowers the ratio of men to women in ten of the metros in our sample, most notably in El Paso, where recent immigrants are almost 11 percentage points more likely to be female than natives, and in San Diego, where their share is 5.6 percentage points higher. ${ }^{14}$

A more even ratio of men to women in the immigrant population suggests a greater prevalence of marriage and family in a particular location, and perhaps more permanence. Because spouses who live apart cannot be linked in the PUMS or ACS data, however, it is

\footnotetext{
${ }^{14}$ The other such metros are Portland, Sacramento, Hartford, Seattle, San Jose, Tucson, Oxnard, and McAllen.
} 
difficult to probe the reasons for the gender imbalances found in particular metros using these data. Intact families may be more likely to settle in the Hispanic, Educated, or Balanced Metros, while men migrating alone may be more likely to seek work in the New Metros. Another possibility is the immigration of families to Hispanic Metros, with male family members continuing on alone to New Metros and sending remittances back to the mothers and children in Hispanic Metros. While we cannot draw any definitive conclusions based on these data, these patterns suggest an interesting area for future research.

In addition to gender, a second way in which immigrants alter the demographics of the communities where they settle is through their effect on the age structure. Immigrants most commonly arrive during their early working years. Recent immigrants are substantially younger than both the general immigrant population and the native population. In 2007 , the average immigrant was about 34 years old and the average recent immigrant just 26 years old-a full 11 years younger than the typical native. ${ }^{15}$

Figure 4 shows average age by nativity in each of the four metrotypes. Overall, immigrants are youngest in the New Metros, where their average age is just 30 . This is not surprising, given that close to half of the immigrant population in these destinations arrived within the preceding decade, and that recent immigrants tend to be younger. The average age of immigrants in the other metrotypes ranges from 34 to 36 . Miami is home to the oldest immigrants, whose average age is 40 . The three metros where immigrants are actually older than local natives are all Hispanic Metros: Miami, McAllen, and El Paso, where immigrants are fully five years older than local natives. At the other end of the spectrum are places like Phoenix, Minneapolis, and Visalia, where immigrants are typically in their late 20 s, more than seven younger than local natives.

\footnotetext{
15 "Recent immigrants" refers to those who arrived within the preceding decade. Children are grouped with their parents, regardless of their own nativity.
} 
Figure 4: Age

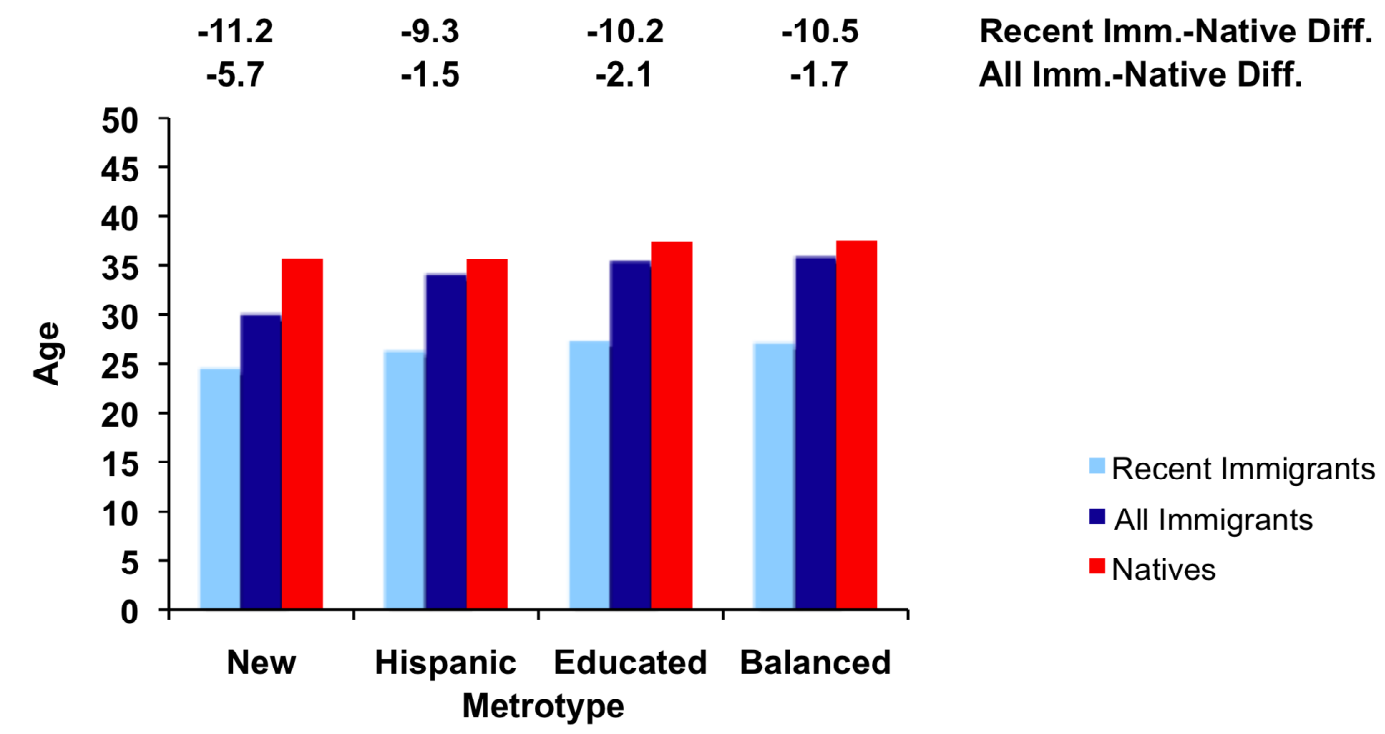

Source: Authors' calculations from 2007 ACS data. See Appendix Table 5.

Note: Immigrants include foreign-born and their children. See text for definition.

However, it is not just the average age, but also the overall age structure that matters for the labor market and fiscal effects of immigration. Similar shares of immigrants and natives are of working age, with about $64 \%$ between the ages of 18 and 65 . However, among immigrants, most of those not of working age are children, while among natives, the majority of those not of working age are elderly.

In Figure 5 we show the average share of the population in each metrotype that is of working age. This fraction varies substantially among recent arrivals, ranging from lows of just $51 \%$ in McAllen and $52 \%$ in El Paso to highs of $71 \%$ in Hartford, Bridgeport, and Orlando. For all nativities, the share tends to be highest in Educated Metros and lowest in Hispanic metros. With the exception of New Metros, the share of the population that is of working age is generally highest among recent immigrants and lowest among natives. 
Figure 5: Share Who Are Working Age

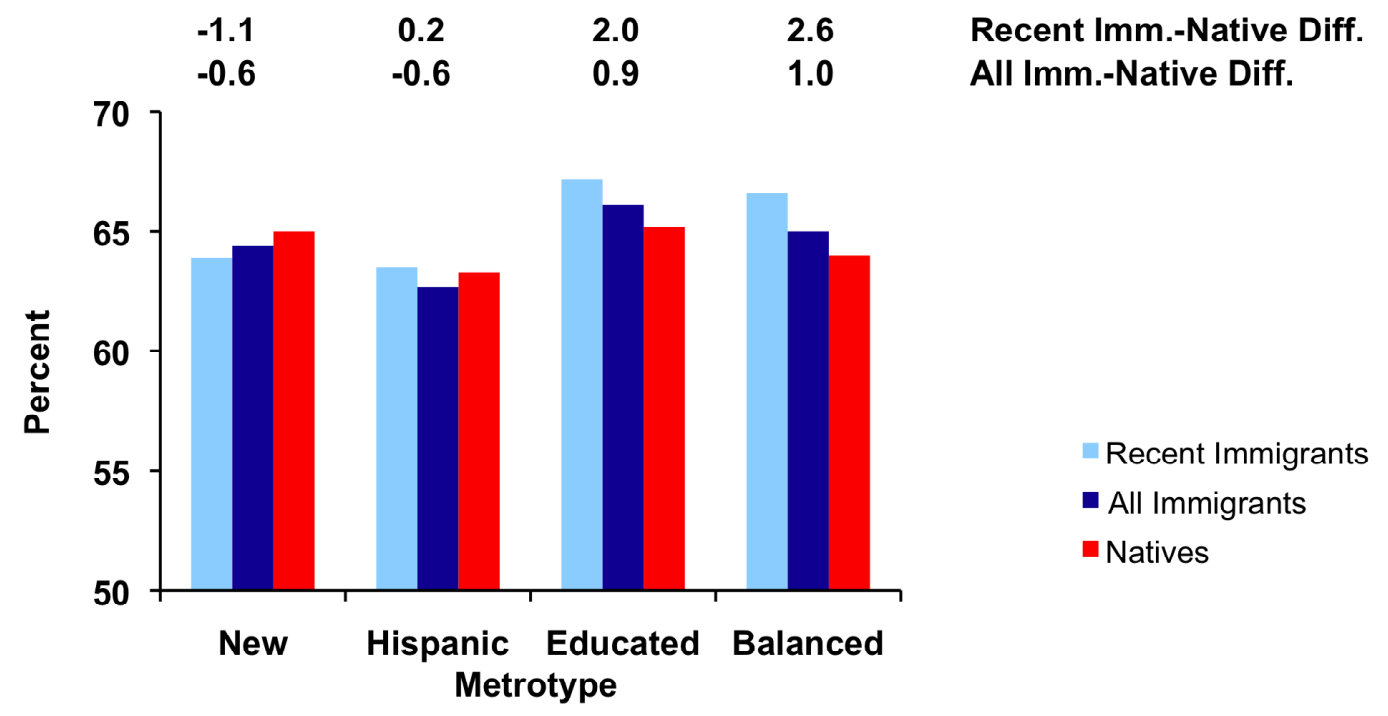

Source: Authors' calculations from 2007 ACS data. See Appendix Table 6.

Note: Immigrants include foreign-born and their children. See text for definition.

\section{The Skill Composition of the Workforce}

An important determinant of the economic impact of immigration is the skill composition of the immigrant workforce. Two important measures of the skills immigrants bring to the labor market are their educational attainment and English language proficiency. A third variable, earnings, reflects the interaction of skills with local opportunities. Aside from the fiscal dimensions of tax revenue and spending on public assistance, immigrants' skills and earnings are important for their broader effects on the labor market, the housing and product markets, and economic conditions more generally. ${ }^{16}$

There is more variation in skills among immigrants than among natives. Immigration tends to lower the educational attainment and English-language proficiency of the

${ }^{16}$ For reviews of the literature, see Friedberg and Hunt (1995) and Borjas (1999). More recent contributions to the debate include Friedberg (2001), Borjas (2003), Ottaviano and Peri (2006), and Jaeger (2007). 
workforce, particularly in Hispanic Metros, but less so in Educated Metros. Immigrant earnings are lowest in New and Hispanic Metros and highest in Educated Metros, both in absolute terms and relative to local natives.

\section{Education}

Immigrants are less educated than natives, on average. The typical working-age native in the United States has completed 13.4 years of schooling. By contrast, among immigrants, the number is 12.0. However, education is also much more variable among immigrants. A greater share of immigrants than natives are high-school dropouts $(30.2 \%$ compared to $10.5 \%)$, and a greater share have been educated beyond college $(10.1 \%$ compared to $8.9 \%)^{17}$

Immigrants overall comprise just over $16 \%$ of the working-age population of the United States, but because of their differing educational distribution, they make up $36 \%$ of dropouts, $16 \%$ of college graduates, and $18 \%$ of those with more than a Bachelors degree. Immigrants are substantially underrepresented among individuals with a high school diploma but less than a bachelor's degree.

The pattern of lower and more variable education among immigrants is borne out at the metropolitan level as well. Average native schooling ranges from a low of 12.4 years in McAllen to a high of 14.5 in Washington. Among immigrants, the averages range more widely, from 8.5 years of schooling in Visalia to 13.9 years in Baltimore.

Figure 6 shows years of schooling in each of the four metrotypes. The top row of numbers in the figure gives the ratio of immigrant to native education levels, as well as the degree to which immigrants have altered the average level of education locally. ${ }^{18}$ Figures 7

\footnotetext{
${ }^{17}$ Roughly equal shares of natives and immigrants stopped their education at the end of college: $26.4 \%$ and $25.5 \%$, respectively.

${ }^{18}$ This is calculated simply as the difference in the overall average education level minus the average native education level. These differences reflect both the relative number of immigrants in a
} 
and 8 show, respectively the share of each group that are high school dropouts and college graduates.

By definition, the most highly educated immigrants are to be found in Educated Metros. The average immigrant in these metros has completed at least a year of college, with over $38 \%$ holding a four-year college diploma or better -a rate even higher than that of natives locally or nationally. One-fifth of immigrants in these places are high-school dropouts, which is the lowest rate in the nation, and "only" 2.6 times the local native rate. Because immigrants' schooling levels are so close to those of natives in these places, there has been a negligible change in the educational composition of the workforce in Educated Metros as a result of immigration.

At the other end of the spectrum, the least educated immigrants can be found in Hispanic Metros, in places like Visalia, Salinas, Fresno, McAllen, and Bakersfield, where the average immigrant has a $9^{\text {th }}$ grade education, and over half never completed high school (63\% in Visalia). Even though natives in Hispanic Metros are also less educated than elsewhere, the schooling gap between immigrants and natives there is a full 2 years, and immigration has led to a 0.7 -year reduction in the average level of education of the local workforce.

The schooling gap between immigrants and natives is actually widest in New Metros (2.1 years), but immigration has an intermediate effect on the education level of the local workforce, with a 0.4 -year reduction. In New Metros, $36 \%$ of all immigrants have not completed high school, and $24 \%$ have graduated from college. Thus, compared to local natives, immigrants are more than four times as likely to have dropped out of high school and about three-quarters as likely to have a Bachelor's degree or better.

metropolitan area and their relative level of education. As with age, these numbers do not capture any causal effect of immigration on local education levels, which could occur through an effect of immigration on native educational attainment or the in migration and outmigration of more and less educated natives. 
Figure 6: Average Years of Education

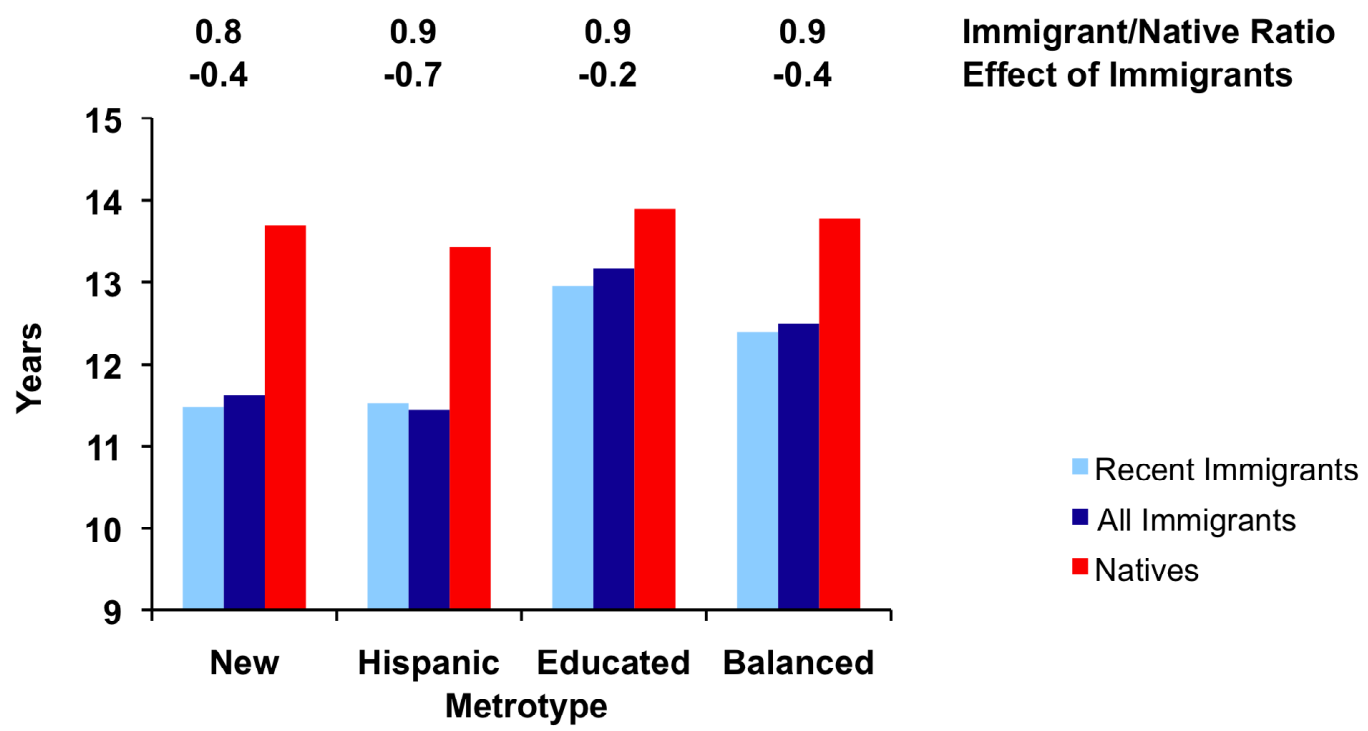

Source: Authors' calculations from 2007 ACS data. See Appendix Table 7. Note: Includes only working-age individuals (age 18-65).

Figure 7: Share Who Are High School Dropouts

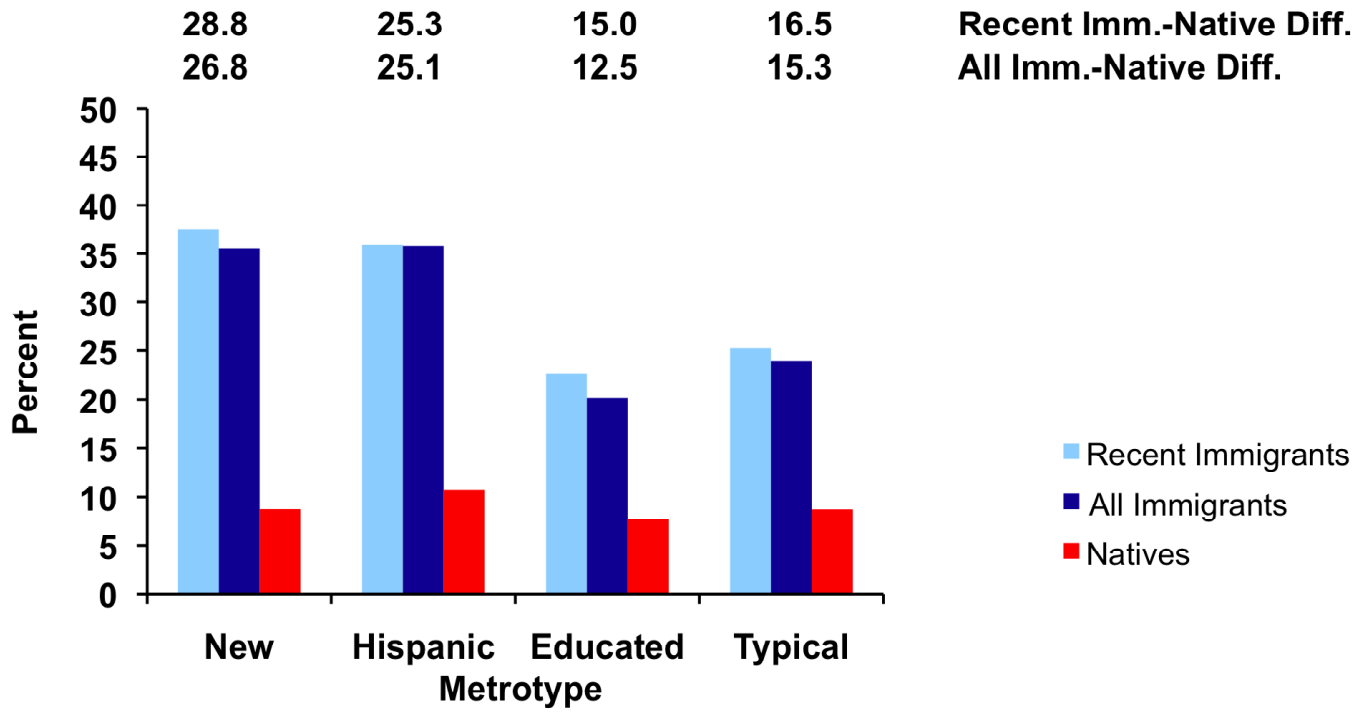

Source: Authors' calculations from 2007 ACS data. See Appendix Table 8.

Note: Includes only working-age individuals (age 18-65) 


\section{Figure 8: Share Who Are College Graduates}

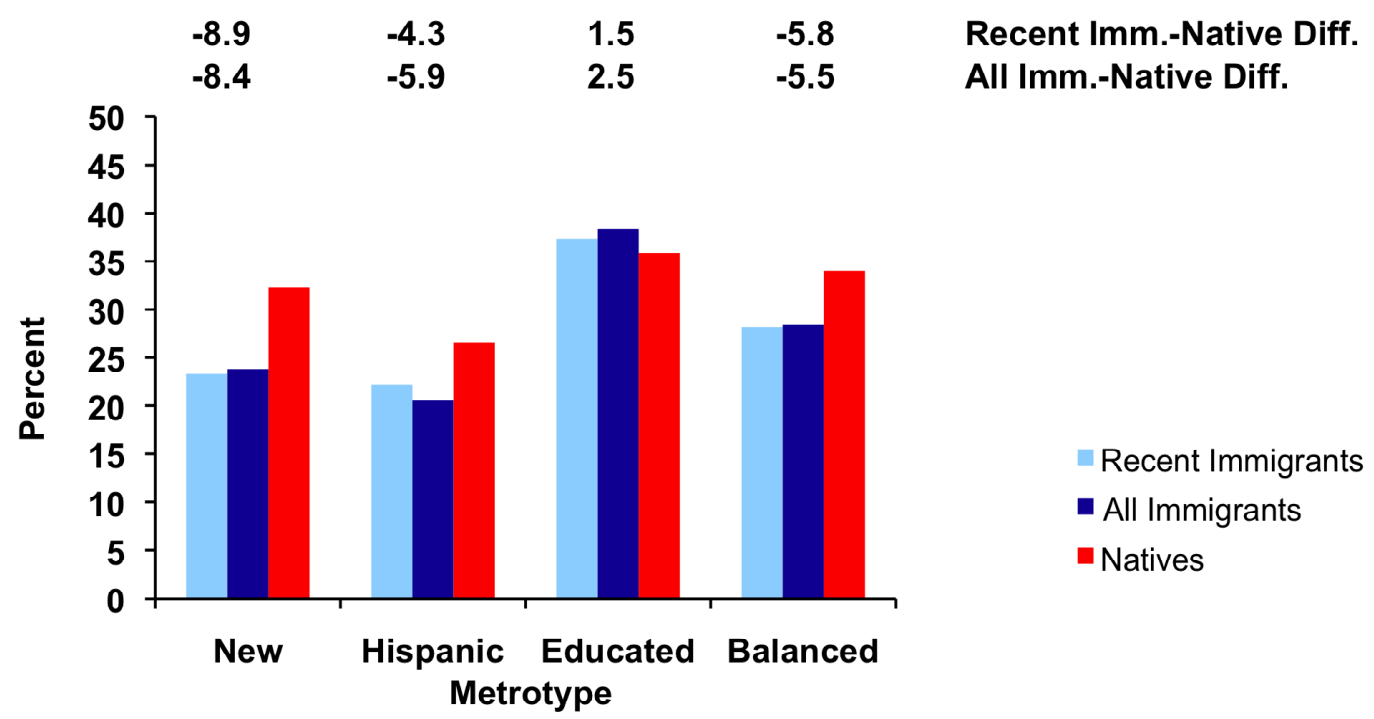

Source: Authors' calculations from 2007 ACS data. See Appendix Table 8. Note: Includes only working-age individuals (age 18-65).

Balanced Metros have immigrants who are more educated than Hispanic or New Metros but less so than Educated Metros, with a schooling gap of 1.3 years between immigrants and natives. The effect of immigrants on the local level of education is a 0.4-year reduction, similar to that of New Metros. In Balanced Metros, a quarter of immigrants never completed high school, about triple the rate of natives. Almost $29 \%$ graduated from college, which means that immigrants are more than four-fifths as likely as natives to have a Bachelor's degree or better.

Figure 9 shows the relationship between immigrant and native schooling levels across metropolitan areas. The diagonal line indicates the average relationship between the two measures. Immigrants clearly tend to be more educated in places with more-educated natives. However, this relationship is even stronger at the two ends of the immigrant education distribution. In Educated Metros, immigrants are relatively well-educated, not just compared to immigrants elsewhere, but also relative to local natives. On the other hand, in 
Hispanic Metros, immigrants are less educated, not only relative to immigrants in other parts of the country, but even in comparison to the local natives, who themselves have relatively low educational attainment.

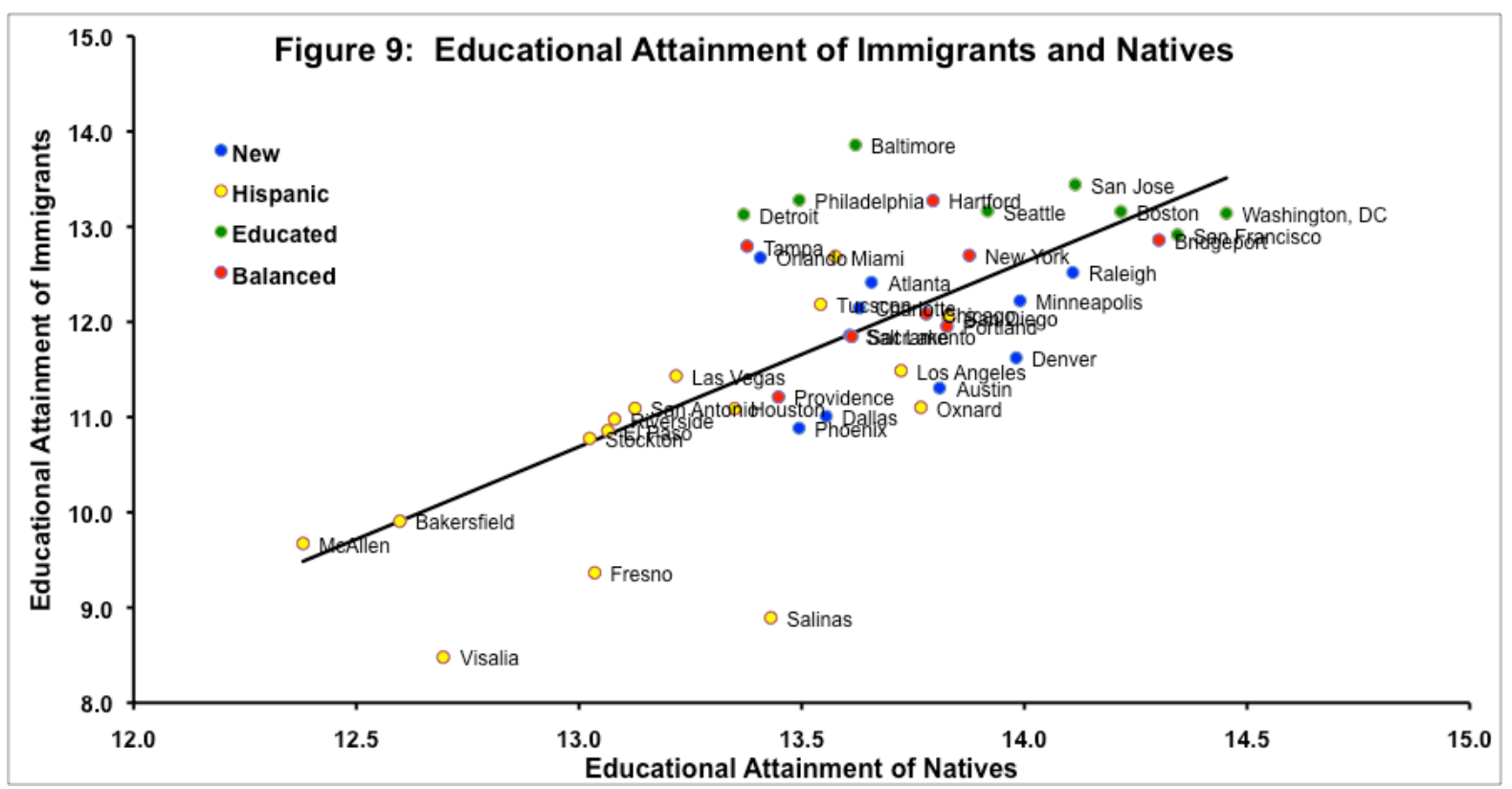

Source: Authors' calculations from 2007 ACS data. See Appendix Table 7. Note: Includes only working-age individuals (age 18-65).

\section{English Language Proficiency}

The ability to speak English is an important skill in the labor market. While it may be possible to function without a working knowledge of English in some immigrant enclaves, limited English ability limits immigrants' labor market opportunities and productivity. English proficiency is, moreover, an important civic skill and a necessary condition for becoming a U.S. citizen. The English language skills of immigrants have declined somewhat in recent years, with less than half $(46.5 \%)$ of working-age immigrants reporting speaking English exclusively or very well in 2007, down almost 2 percentage points from 2000, and nearly 7 percentage points since 1990. Recent immigrants are almost 12 percentage points less likely than immigrants overall to report a high level of English proficiency. 
Figure 10 presents the share of immigrants who self-report that they speak English exclusively or very well. There is substantial geographic variation in immigrants' English language ability. In Educated Metros, most immigrants are fluent -- 54\% on average, with as many as $65 \%$ in Baltimore. In Hispanic Metros, English proficiency tends to be lower, around $40 \%$ overall, with as few as $22 \%$ in Visalia, $26 \%$ in Salinas, and $29 \%$ in McAllen. While some of this difference reflects the fact that immigrants in Educated Metros tend to have been in the U.S. longer, it is not the only reason behind the pattern. Recent immigrants in Educated Metros also speak better English than recent immigrants elsewhere. It is also notable that immigrants in New Metros are more likely to speak English very well than those in Hispanic Metros.

\section{Figure 10: English Proficiency}

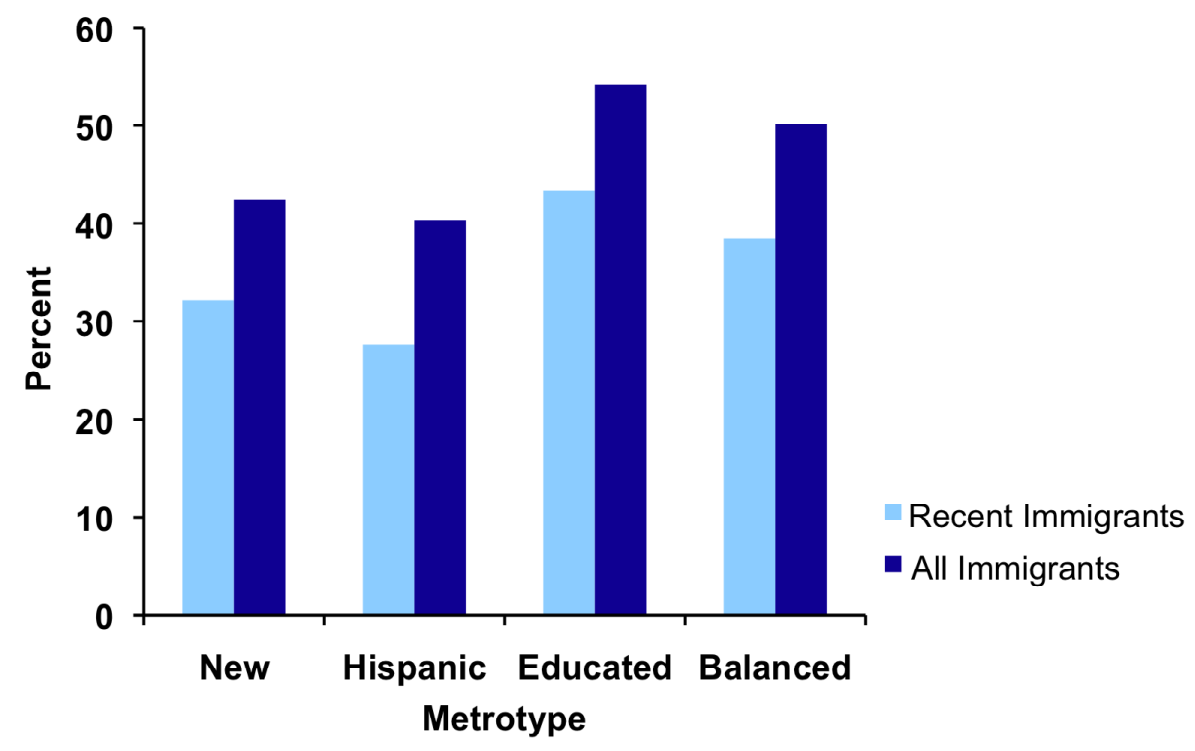

Source: Authors' calculations from 2007 ACS data. See Appendix Table 9.

Note: Includes only working-age individuals (age 18-65). English proficency is defined as speaking English "only" or "very good". 


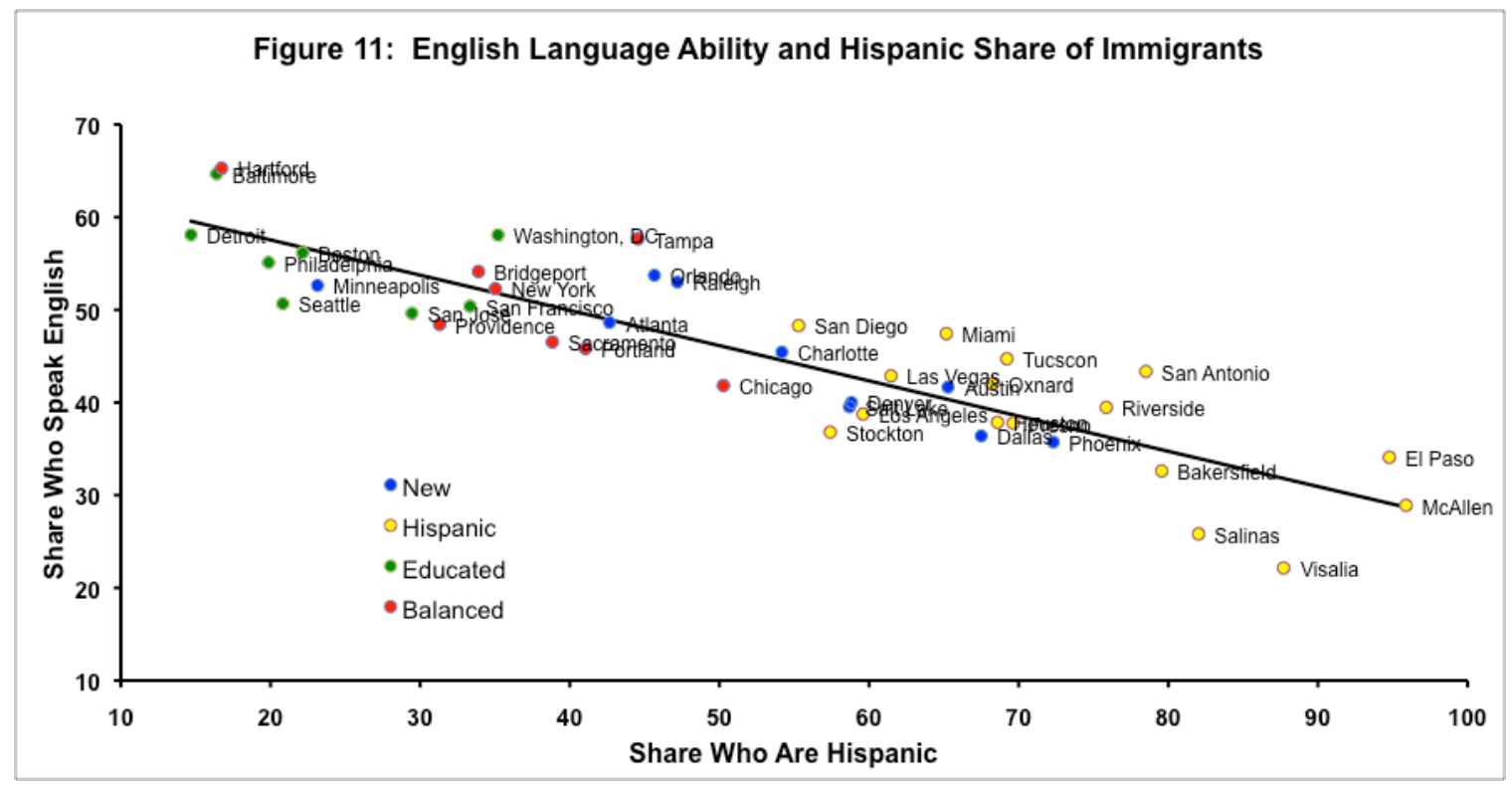

Source: Authors' calculations from 2007 ACS data. See Appendix Table 9.

Note: Includes only working-age individuals (age 18-65). English proficiency is defined as speaking English "only" or "very good".

Not surprisingly, geographic variation in English proficiency is highly correlated with the origin-country composition of local immigrants. Figure 11 presents the relationship between the share of immigrants who speak English very well or exclusively and the share of immigrants who are Hispanic, both measured in the working-age population. This relationship is very strong, with a correlation of -0.93 between the two measures. Hispanics make up close to two-thirds of immigrants in Hispanic Metros, and over $80 \%$ in places like McAllen, El Paso, Visalia, and Salinas. They are only $27 \%$ of the immigrants in Educated Metros and $38 \%$ of those in Balanced Metros, with a low of $15 \%$ in Detroit. Within the New Metros, Hispanics make up $57 \%$ of the immigrant population, and there is a strong negative relationship between this share and English proficiency $(-0.88)$. There are also very strong correlations between the share of immigrants who are Hispanic and their educational 
attainment (-0.88) and between their educational attainment and English language proficiency (0.92). ${ }^{19}$

\section{Wages}

The hourly earnings patterns of immigrants and natives across metropolitan areas closely parallel those observed for education. Not surprisingly, recent immigrants earn less than other immigrants, with both earning less than natives. At the national level in 2007, average hourly wages for these three groups were $\$ 16.84, \$ 20.29$, and $\$ 22.05$, respectively. ${ }^{20}$

Figure 12 shows how wage levels vary geographically. These wages are unadjusted for differences across areas in workers' average education, age, gender, etc., and so the observed patterns, in part, reflect those differences. The top rows of the figure show two related statistics. First is the ratio of immigrant to native wages, which varies widely from place to place. Second is the compositional effect of immigrants on the overall metropolitan wage level. ${ }^{21}$

An interesting empirical regularity is that immigrants tend to earn less, relative to natives, in metropolitan areas with more immigrants. ${ }^{22}$ The earnings gap is also wider where immigrants are less educated. For example, the four metropolitan areas where immigrants have the lowest relative wages are all Hispanic Metros. ${ }^{23}$ Immigrants earn about one-third less than natives in these four places, where the average share of immigrants in the

\footnotetext{
${ }^{19}$ The absolute value of all three correlations is around 0.9 .

${ }^{20}$ Hourly wages are calculated as annual wage and salary income, divided by weeks worked, divided by hours worked per week. All monetary figures are in 2008 dollars.

${ }^{21}$ As with education, this is simply the difference between the overall average wage and the native average wage within a metropolitan area. It is therefore a purely compositional, not causal, effect.

${ }^{22}$ This correlation holds across the full set of 42 metros in the sample, though it is not apparent from simply comparing the four metrotype averages. New Metros resemble Hispanic Metros, with low earnings among both immigrants and natives, as well as for immigrants relative to natives. However, the share of immigrants in the population is much higher in Hispanic Metros than New Metros.

${ }^{23}$ The four metros where immigrants' wages are lowest, relative to natives, are Visalia, Salinas, Oxnard, and Fresno.
} 
population is $35 \%$-- far above the national average of one-sixth. In Educated Metros, there is close to earnings parity between immigrants and natives, and in Detroit, immigrants actually earn more than natives.

In terms of immigrants' contribution to prevailing wage levels, these two effects magnify each other. In Educated Metros, immigrants are a relatively small part of the labor force, and the earnings gap with natives is the smallest of any metrotype. ${ }^{24}$ Immigrants in Educated Metros therefore have a relatively minor effect on the overall level of wages in these metropolitan areas, reducing the average local wage by around 40 cents. In Hispanic Metros, low relative wages coupled with high shares of the labor force combine to reduce local average wages by a full $\$ 1.81$.

Figure 12: Wages $(2008 \$)$

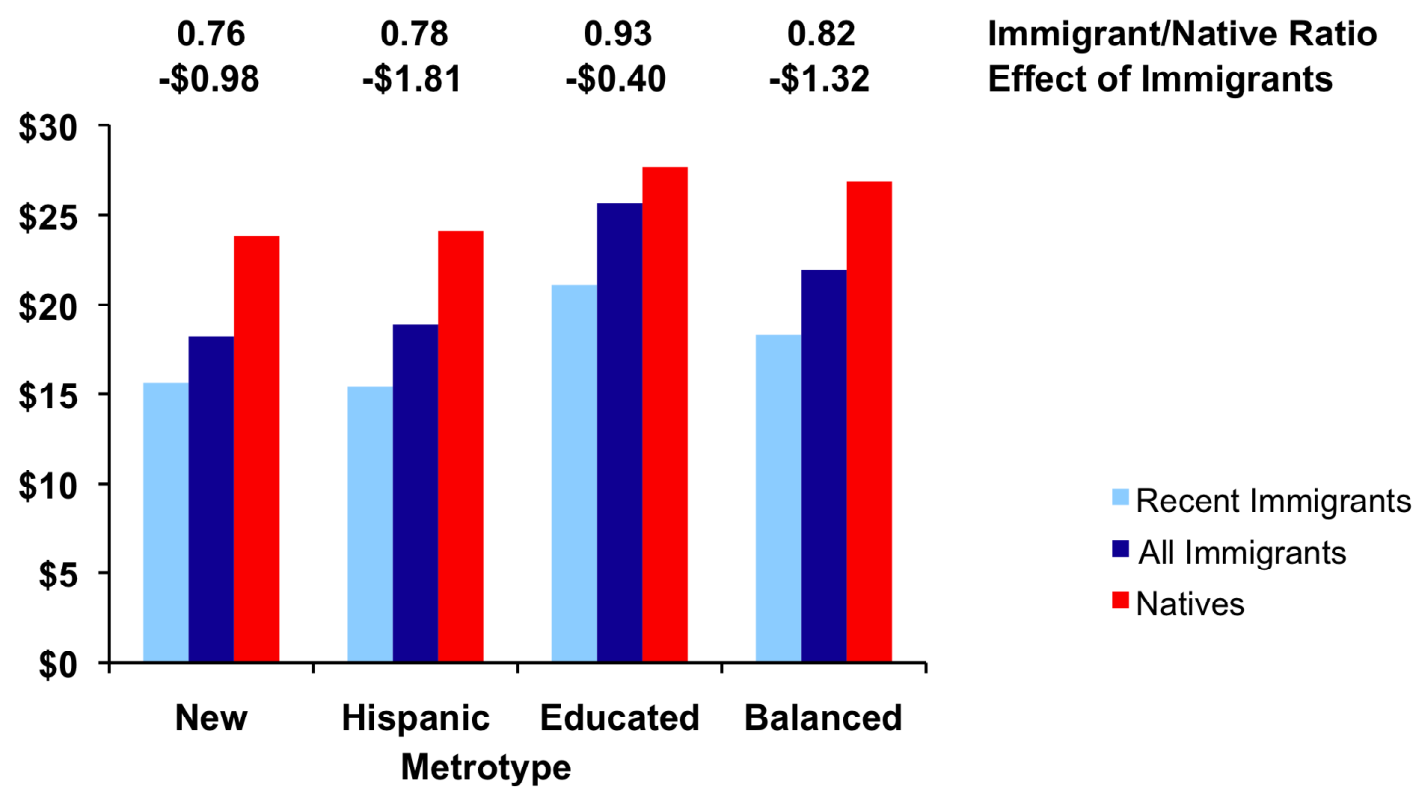

Source: Author's calculations from 2007 ACS data. See Appendix Table 10.

Note: Includes only employed working-age individuals (age 18-65)

${ }^{24}$ The share of immigrants in the labor force differs from their share in the population because of differences in the labor force participation rates of natives and immigrants. There is substantial geographic variation in the proportion of the labor force that is foreign-born, ranging from a high of $46 \%$ in San Jose to under $10 \%$ in Baltimore. In the U.S. as a whole, immigrants were $15.9 \%$ of the labor force in 2007 , up from $12.8 \%$ in 2000. 
There is strong correlation between the educational attainment, English-language proficiency, and earnings of immigrants across metropolitan areas. This suggests that any one of these measures can be used as a rough summary of the skill profile of the local immigrant workforce for purposes of considering the impact of immigration on the local economy.

\section{E. Unemployment, Poverty, and Public Assistance}

One of the key concerns of state and local policy makers regarding immigration is the potential burden imposed on public budgets. On the one hand, immigrants pay taxes, including income, sales, and property taxes. On the other hand, they make use of public services and programs. There are strong limitations on the eligibility of non-citizens for means-tested public benefits, but some states do extend access to Temporary Assistance for Needy Families (TANF) and Medicaid to those who satisfy certain conditions. All immigrants, including the undocumented and their families, can make use of governmentfunded services like public schools, public-hospital emergency rooms, and emergency services.

The fiscal effects on different metropolitan areas depend not only on the number of immigrants who have settled there, but also on their characteristics. Working-age people in well-paying jobs with health insurance coverage are less likely to pose a fiscal burden than unemployed people with few marketable skills. The youngest and oldest people in the population also tend to require more public spending.

Despite higher poverty rates, immigrants are less likely than natives to be on welfare. Before the onset of the deep recession, immigrants also had lower rates of unemployment than natives, particularly in New Metros. 


\section{Unemployment}

In the first quarter of 2009 , the national unemployment rate among immigrants was $9.7 \%$, compared to $8.6 \%$ among natives. The major recession of the preceding months brought about a much larger increase in joblessness among immigrants than among natives, consistent with research that has found immigrants to be more sensitive to prevailing economic conditions (See Bratsberg, Barth, and Raaum, 2006). Before the recession, in 2007, unemployment was actually less widespread among immigrants overall than natives, with unemployment rates of $5.4 \%$ and $6.1 \%$, respectively, though unemployment was higher among recent immigrants $(6.2 \%){ }^{25}$

Figure 13 presents the average unemployment rate across metrotype by nativity. For all three nativity groups, unemployment rates were highest in Hispanic Metros and lowest in New Metros. The jobless rate among new arrivals was farthest below that of natives in New Metros. To the degree that new immigrants are drawn to these metros for jobs, it makes sense that their unemployment rates would be particularly low here. Elsewhere, native and new-immigrant unemployment rates were quite similar. The native unemployment rate was highest in Hispanic and Balanced Metros, and almost all of the places where the native jobless rate exceeded that of immigrants in 2007 were located in these two metrotypes. Immigrant unemployment rates tend to be higher in metropolitan areas where there is higher native unemployment, and where immigrant educational attainment and wages are lower.

\footnotetext{
${ }^{25}$ In 2000 , the unemployment rates were $7.9 \%$ for new immigrants, $6.7 \%$ for all immigrants, and $5.2 \%$ for natives.
} 


\section{Figure 13: Unemployment Rate}

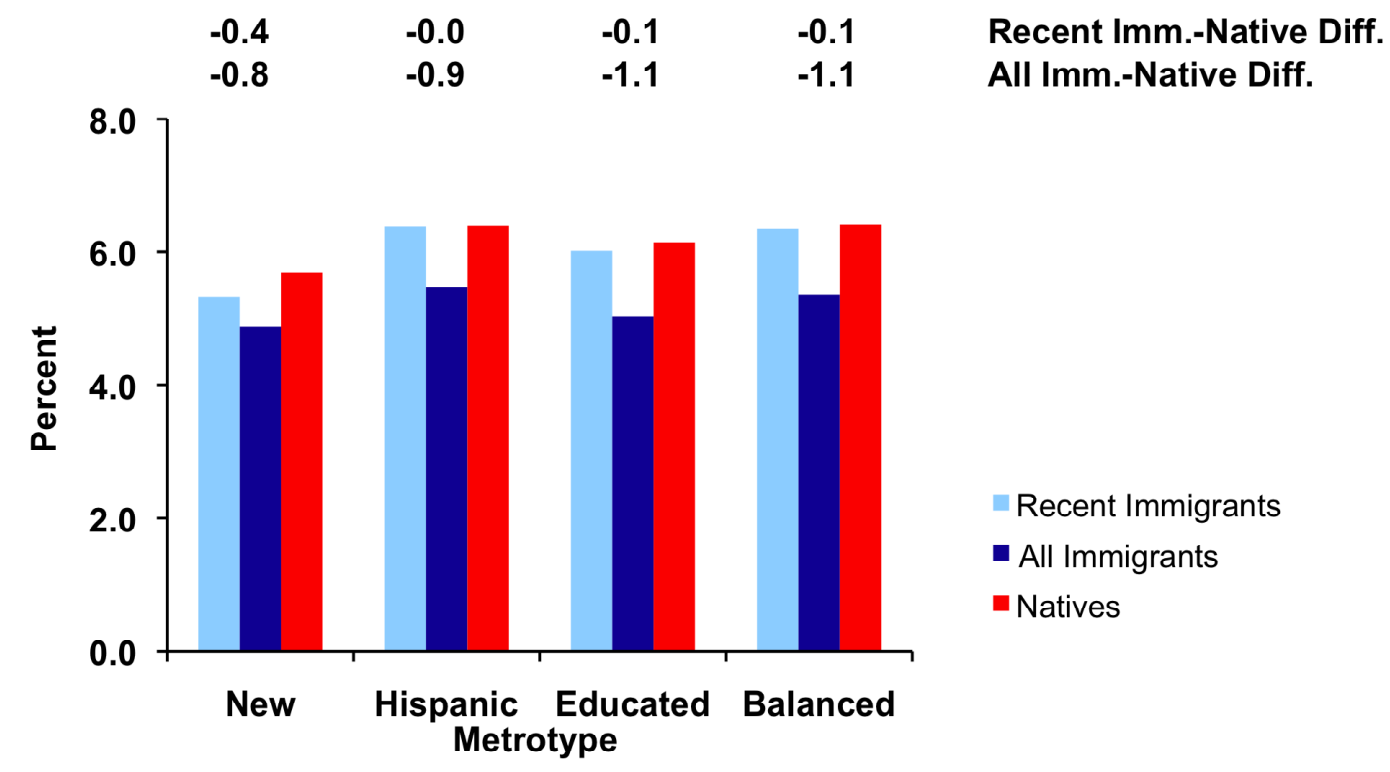

Source: Authors' calculations from 2007 ACS data. See Appendix Table 11.

Note: Among working-age (18-65) individuals who are in the labor force.

\section{Poverty and Public Assistance}

Earlier, we showed that immigrants generally have lower earnings than natives. Particularly in areas where immigrant households include many children, one might therefore expect to find higher poverty rates among immigrants, and perhaps greater use of public assistance. Roughly one in five individuals (22\%) living in poverty is an immigrant or the child of immigrants, and $16 \%$ of immigrants live below the poverty line, compared to $11 \%$ of natives. In terms of public assistance usage, $13 \%$ of those on welfare are immigrants or the children of immigrants. In other words, despite their higher poverty rates, immigrants are less likely than natives to be on welfare, with rates of $0.8 \%$ and $1 \%$, respectively. 


\section{Figure 14: Average Poverty Rates}

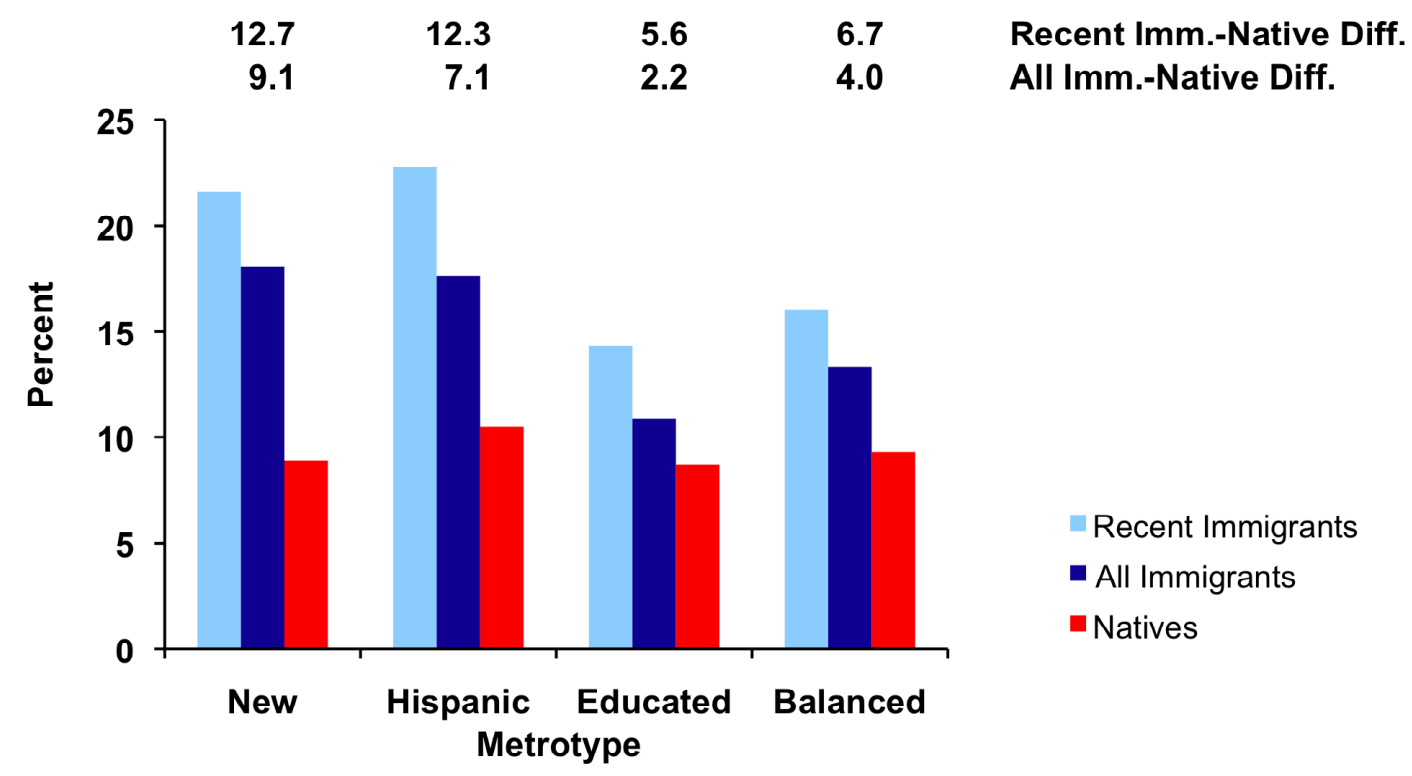

Source: Authors' calculations from 2007 ACS data. See Appendix Table 12.

Note: Immigrants include foreign-born and their children. See text for definition.

In Figure 14, we show the share of people living below the poverty line. ${ }^{26}$ Immigrants are, in every metropolitan area, more likely to be poor than natives, with recent immigrants having an even higher poverty rate than immigrants in general. As is the case with respect to earnings, immigrants have the worst outcomes in New and Hispanic Metros, where the immigrant poverty rates of around $18 \%$ are more than 7 percentage points higher than the poverty rates of natives. The share of recent arrivals living in poverty are $22 \%$ and $23 \%$ in New and Hispanic Metros, respectively, more than double the poverty rates of local natives. Not surprisingly, the poverty gap is smallest in the Educated Metros, where immigrants are only about one-quarter more likely to be poor than natives. The lowest

\footnotetext{
${ }^{26}$ As with the age calculations, the native-born children of immigrants are classified here as immigrants.
} 
immigrant poverty rate is to be found in Bridgeport (7\%), and the highest in EI Paso (40\%) and McAllen (47\%), where the majority of recent immigrants also live below the poverty line.

Figure 15: Public Assistance Rates

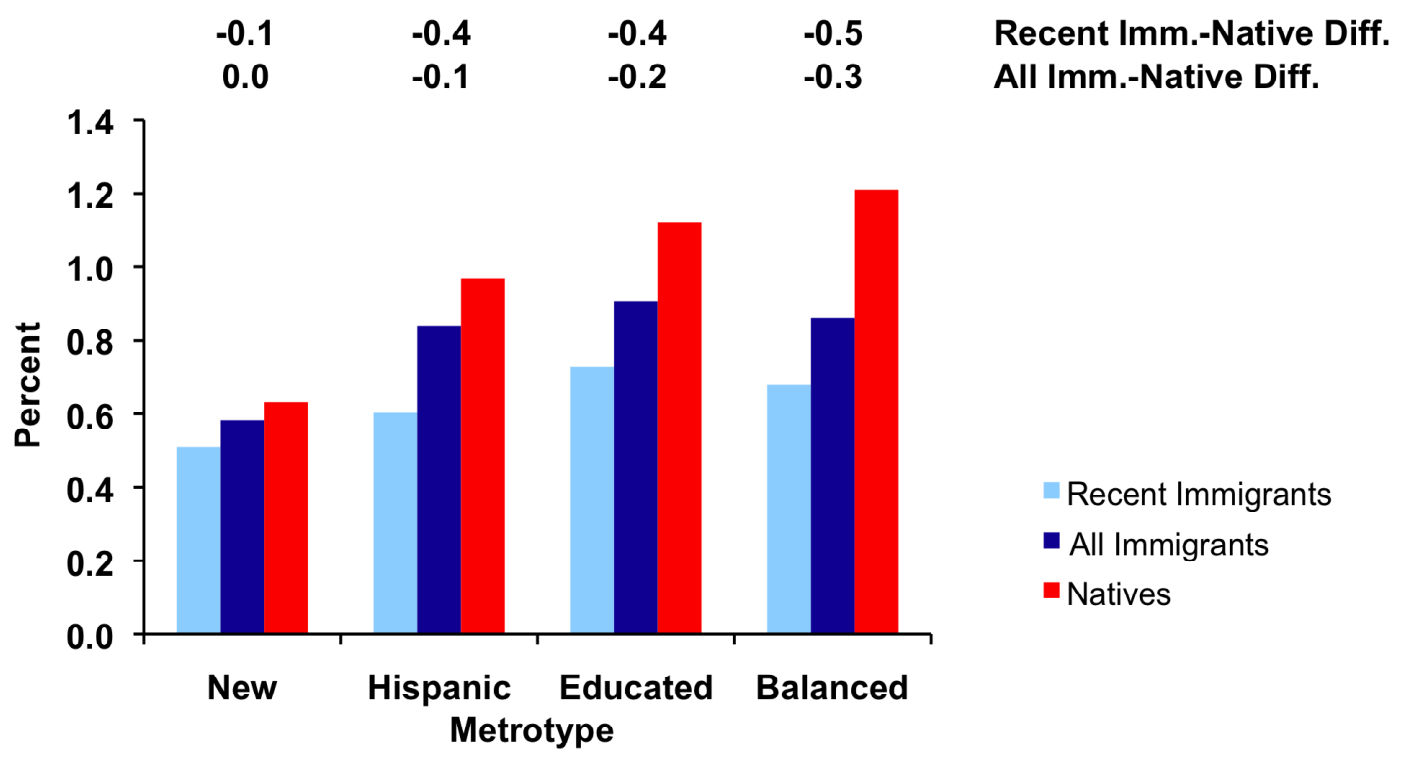

Source: Author's calculations from 2007 ACS data. See Appendix Table 13.

Note: Immigrants include foreign-born and their children. See text for definition.

Public Assistance in this figure is GA and TANF.

Figure 15 shows rates of public assistance receipt, specifically TANF and General Assistance, which, as expected, follow a similar geographic pattern, with immigrants in Hispanic Metros being most likely to receive welfare. In general, recent immigrants are less likely to receive public assistance than earlier cohorts. This may reflect lower rates of eligibility among recent immigrants in these places, either because they have not yet been in the country the requisite 5 years, or because they are undocumented. Future work could explore whether there is an inverted $U$-shaped pattern to immigrant take-up of public assistance. In general, however, the differences in the probability of receiving welfare between immigrants and natives are relatively small. The averages do nevertheless mask 
some variation across metropolitan areas. For example, immigrants are more than twice as likely as natives to receive public assistance in Minneapolis. But in other new immigrant destinations like Atlanta, Raleigh-Durham, and Dallas, immigrants are less likely than natives to receive public assistance, despite their higher poverty rates.

\section{Conclusion}

National debate over immigration in the United States tends to view its effects through an aggregate lens. However, immigration means very different things in different metropolitan areas. Understanding the heterogeneity of local experiences requires going beyond the fact that some areas receive more immigrants than others to recognizing that immigrants' demographic and economic characteristics also vary widely from place to place. This is due not only to the fact that different kinds of immigrants have settled in different parts of the country, but also to the varying ways in which those patterns of settlement have in turn affected immigrant outcomes. Furthermore, the impact that immigrants have on native outcomes depends not only on their own numbers and characteristics, but also on the demographic and economic features of the communities they join.

Along most dimensions, there is more diversity among immigrants than among natives, as well as more geographic variation in their traits. This study examines the characteristics of immigrants and natives in the 42 metropolitan areas with the largest immigrant populations nationwide, focusing on the ways in which immigrants' outcomes and impacts differ from place to place. Metropolitan areas are characterized as falling into one of four broad types:

First are what we term New Immigrant Metros-places like Raleigh-Durham and Atlanta- where a sizable fraction of local immigrants are recent arrivals. These are the areas of fastest growth in immigration. However, because native population growth is also high in these cities, immigration plays only a moderate role in population growth overall. The 
typical immigrant in a New Immigrant Metro is more likely than one elsewhere to be a recently-arrived young working man without children. Still, one in five schoolchildren in these communities is the child of immigrants, and they are responsible for half of growth in the school-age population. Immigrants in New Immigrant Metros earn less than immigrants elsewhere (including relative to local natives), however their rate of unemployment is lower.

The second category, Hispanic Immigrant Metros, comprises places where a substantial majority of immigrants come from Spanish-speaking countries, the share of immigrants in the general population is relatively high, and the fraction of them recentlyarrived is relatively low. Almost all of these metros are located in California or Texas. Immigrants in these communities tend to be less educated and less proficient in English than those elsewhere. There are also more children among them, comprising $40 \%$ of the local school-age population. About half of growth in the overall and school-age populations in these communities is attributable to immigration. The labor market outcomes of immigrants in Hispanic Immigrant Metros are worse than those of immigrants in most other places, with a combination of low wages and high unemployment, even in comparison to local natives, whose outcomes are among the worst nationwide. High poverty rates in these immigrant communities make the challenges facing local policymakers greater than in other parts of the country.

In sharp contrast are Educated Immigrant Metros_cities like San Jose and Boston-where over one-third of immigrants are college graduates. The native populations of these places are stagnant or declining, such that all growth in both the general and school-age populations is due to the arrival of immigrants and the birth of their children. One in five schoolchildren in these metros has immigrant parents, the same proportion as that of immigrants in the overall population. Immigrants in these areas earn nearly as much as local natives, who are the highest earning natives in the country. 
Finally, there are the Balanced Immigrant Metros, where immigrants are of mixed origin, recency, and education. This group includes cities like New York and Chicago. It is in these places that immigration is most representative of national trends. Compared to natives, immigrants here are younger, less educated, and more male. Immigrants account for most population growth. About one in four schoolchildren is the child of immigrants, and in many places, all growth in the school-age population is due to immigration. Labor market outcomes in these areas are typical for those of immigrants nationwide.

In conclusion, there is wide variation in what immigration means in different communities. Beyond resolving the national-level questions of how many and what kind of immigrants to admit to the country, successful immigration policy reform in the United States will need to acknowledge and address this variety of experience. While state and local policymakers cannot directly control the number and type of immigrants who settle in their jurisdictions, they do have the power to regulate many aspects of their experience as workers and residents, and in this way to create atmospheres that are more or less conducive to immigrant incorporation. In the face of national legislative paralysis, many states and municipalities have passed ad-hoc (and sometimes unconstitutional) laws designed to address immigration themselves. ${ }^{27}$ Finding ways for national policy to take into account the divergent impact of immigration on different places, and in particular, to provide support to those communities most challenged by immigration, may provide the key to

${ }^{27}$ On the one hand are places like Hazleton, Pennsylvania; Farmers Branch, Texas (a suburb of Dallas); and Valley Park, Missouri (a suburb of St. Louis), which have sought to deflect illegal immigration by penalizing those who employ or rent to them. Suburbs of Washington and Atlanta have taken steps to regulate day-labor sites and English-only signage, respectively. Los Angeles has made use of maximum-occupancy laws to deflect immigration (Light, 2006). On the other hand are places like Littleton, Colorado, with its citizenship-mentoring program, and El Paso, Texas, which offers early-childhood and parenting classes, intended to reduce poverty among local immigrants. Hartford and New Haven, Connecticut, and San Francisco

provide municipal identity cards entitling residents to city services, regardless of their legal status. A flurry of state and local legislation addresses other things as well, including empowering local police to enforce immigration law, limiting eligibility for in-state tuition or drivers' licenses, or, on the other hand, providing state identity cards to enable those who lack social security numbers to pay taxes and open bank accounts. 
breaking the political impasse that has stood in the way of comprehensive national immigration reform.

\section{REFERENCES}

Borjas, George (1999) "The Economic Analysis of Immigration," in Handbook of Labor Economics, Volume 3A, edited by Orley Ashenfelter and David Card, Amsterdam: North-Holland,1697-1760.

Borjas, George (2003) "The Labor Demand Curve Is Downward Sloping: Reexamining the Impact of Immigration on the Labor Market," Quarterly Journal of Economics 118(4):1335-1374.

Borjas, George J., Richard B. Freeman, and Lawrence F. Katz (1997) "How Much Do Immigration and Trade Affect Labor Market Outcomes?" Brookings Papers on Economic Activities 1997(1):1-90.

Bratsberg, Bernt, Erling Barth and Oddbjørn Raaum (2006) "Local Unemployment and the Relative Wages of Immigrants: Evidence from the Current Population Surveys," The Review of Economics and Statistics, 88(2):243-263

Card, David (2007) How Immigration Affects U.S. Cities, Centre for Research and Analysis on Migration, University College-London, Discussion Paper 11/07, July.

Card, David and Ethan Lewis (2007) "The Diffusion of Mexican Immigrants during the 1990s: Explanations and Impacts," in Mexican Immigration to the United States, George J. Borjas editor, Chicago: University of Chicago Press.

Friedberg, Rachel M. (2001) "The Impact of Mass Migration on the Israeli Labor Market," The Quarterly Journal of Economics, 116(4):1373-1408.

Friedberg, Rachel M. and Jennifer Hunt (1995) "The Impact of Immigrants on Host Country Wages, Employment, and Growth," Journal of Economic Perspectives, 9(2):23-44.

Hernández-León, Ruben, and Victor Zúñiga, editors (2005) New Destinations: Mexican Immigration in the United States, New York: The Russell Sage Foundation.

Jaeger, David A. (2007), Skill Differences and the Effect of Immigrants on the Wages of Natives, College of William and Mary, mimeo.

Jaeger, David A., Susanna Loeb, Sarah E. Turner, and John Bound (1998) Coding Geographic Areas Across Census Years: Creating Consistent Definitions of Metropolitan Areas, NBER Working Paper 6772, October.

Light, Ivan (2006) Deflecting Immigration: Networks, Markets, and Regulation in Los Angeles, New York: Russell Sage Foundation. 
Massey, Douglas S. (2008) New Faces in New Places. New York: Russell Sage Foundation.

Ottaviano, Gianmarco I.P, and Giovanni Peri (2006) Rethinking the Effect of Immigration on Wages, NBER Working Paper 12497, August.

Passel, Jeffrey S., and D'Vera Cohn (2009) A Portrait of Unauthorized Immigrants in the United States, Pew Hispanic Center Report, April.

Singer, Audrey (2004) The Rise of New Immigrant Gateways, Brookings Institution, March.

Singer, Audrey, Susan W. Hardwick, and Caroline Brettell, editors (2008) Twenty-First Century Gateways, Washington, DC: The Brookings Institution. 
Appendix Table 1

Immigration and the Population, 2007

\begin{tabular}{|c|c|c|c|c|c|c|c|}
\hline \multirow[b]{2}{*}{$\begin{array}{l}\text { Metrotype/ } \\
\text { Metropolitan Area }\end{array}$} & \multicolumn{2}{|c|}{ Population } & \multirow{2}{*}{$\begin{array}{l}\text { Immigrant } \\
\text { Share of } \\
\text { Population }\end{array}$} & \multirow{2}{*}{$\begin{array}{l}\text { Share of } \\
\text { Immigrants } \\
\text { Arrived } \\
\text { within } 10 \\
\text { years }\end{array}$} & \multicolumn{2}{|c|}{$\begin{array}{c}\text { Average Annual } \\
\text { Population Growth }\end{array}$} & \multirow{2}{*}{$\begin{array}{c}\text { Share of } \\
\text { Population } \\
\text { Growth Due } \\
\text { to } \\
\text { Immigration }\end{array}$} \\
\hline & $\begin{array}{c}\text { Immigrants } \\
\text { (millions) }\end{array}$ & $\begin{array}{c}\text { Natives } \\
\text { (millions) }\end{array}$ & & & Immigrants & Natives & \\
\hline Full U.S. 2007 (by parentage) & 48.7 & 252.9 & 16.2 & 36.3 & 3.20 & 0.61 & 47.7 \\
\hline Full U.S. 2007 (by nativity) & 38.0 & 263.6 & 12.6 & 37.9 & 2.91 & 0.74 & 26.4 \\
\hline 42 Metros 2007 (by parentage & 37.7 & 103.3 & 26.7 & 34.9 & 2.89 & 0.79 & 55.2 \\
\hline 42 Metros 2007 (by nativity) & 29.3 & 111.8 & 20.7 & 36.5 & 2.63 & 1.00 & 39.3 \\
\hline Full U.S. 2000 (by parentage) & 39.1 & 242.3 & 13.9 & 40.3 & 5.11 & 0.77 & 46.0 \\
\hline Full U.S. 2000 (by nativity) & 31.1 & 250.3 & 11.1 & 42.4 & 4.69 & 0.92 & 34.4 \\
\hline \multicolumn{8}{|l|}{ New } \\
\hline Atlanta & 0.85 & 4.29 & 16.6 & 51.8 & 7.75 & 2.44 & 34.3 \\
\hline Austin & 0.31 & 1.35 & 18.4 & 45.8 & 6.37 & 2.74 & 31.5 \\
\hline Charlotte & 0.19 & 1.51 & 11.3 & 57.7 & 7.87 & 2.66 & 23.8 \\
\hline Dallas & 1.47 & 4.65 & 24.0 & 42.7 & 5.44 & 1.67 & 47.2 \\
\hline Denver & 0.40 & 2.08 & 16.1 & 43.4 & 4.55 & 1.28 & 37.6 \\
\hline Minneapolis & 0.37 & 2.72 & 11.8 & 51.7 & 5.42 & 0.64 & 48.9 \\
\hline Orlando & 0.40 & 1.63 & 19.9 & 40.8 & 7.66 & 2.06 & 42.9 \\
\hline Phoenix & 0.99 & 3.24 & 23.5 & 45.0 & 7.80 & 2.54 & 43.8 \\
\hline Raleigh-Durham & 0.22 & 1.27 & 14.8 & 56.6 & 8.34 & 2.67 & 30.7 \\
\hline Salt Lake City & 0.16 & 0.85 & 15.8 & 49.9 & 5.10 & 1.20 & 40.8 \\
\hline All New & 5.36 & 23.58 & 18.5 & 46.6 & 6.53 & 1.94 & 39.2 \\
\hline \multicolumn{8}{|l|}{ Hispanic } \\
\hline Bakersfield & 0.23 & 0.56 & 29.4 & 30.3 & 6.07 & 1.70 & 55.7 \\
\hline El Paso & 0.27 & 0.47 & 36.1 & 28.5 & 0.75 & 1.45 & 23.1 \\
\hline Fresno & 0.28 & 0.62 & 31.3 & 28.1 & 1.70 & 1.56 & 33.1 \\
\hline Houston & 1.61 & 3.97 & 28.9 & 39.1 & 4.67 & 1.84 & 48.1 \\
\hline Las Vegas & 0.53 & 1.30 & 29.0 & 37.4 & 7.66 & 3.03 & 46.7 \\
\hline Los Angeles & 6.04 & 6.84 & 46.9 & 26.0 & 0.63 & 0.53 & 51.3 \\
\hline McAllen & 0.29 & 0.42 & 40.4 & 33.2 & 2.98 & 3.53 & 36.9 \\
\hline Miami & 2.39 & 2.96 & 44.7 & 34.4 & 1.82 & 0.45 & 75.6 \\
\hline Oxnard & 0.24 & 0.56 & 30.5 & 28.0 & 2.14 & 0.29 & 75.2 \\
\hline Riverside & 1.29 & 2.79 & 31.7 & 26.8 & 5.95 & 2.22 & 52.1 \\
\hline Salinas & 0.19 & 0.27 & 40.7 & 32.3 & 0.93 & -0.36 & 243.2 \\
\hline San Antonio & 0.28 & 1.68 & 14.1 & 32.4 & 3.57 & 1.96 & 22.0 \\
\hline San Diego & 0.87 & 2.11 & 29.1 & 29.8 & 1.31 & 0.63 & 45.6 \\
\hline Stockton & 0.23 & 0.44 & 33.8 & 30.5 & 5.56 & 1.25 & 65.8 \\
\hline Tucscon & 0.17 & 0.80 & 17.5 & 38.9 & 3.94 & 1.59 & 32.4 \\
\hline Visalia & 0.15 & 0.27 & 35.6 & 33.8 & 3.36 & 1.26 & 57.6 \\
\hline All Hispanic & 15.05 & 26.06 & 36.6 & 30.0 & 2.20 & 1.25 & 49.5 \\
\hline \multicolumn{8}{|l|}{ Educated } \\
\hline Baltimore & 0.25 & 2.37 & 9.5 & 42.9 & 5.43 & 0.19 & 71.4 \\
\hline Boston & 0.87 & 3.76 & 18.9 & 40.9 & 2.45 & -0.14 & 136.8 \\
\hline Detroit & 0.49 & 3.97 & 11.1 & 38.6 & 3.04 & -0.25 & 389.1 \\
\hline Philadelphia & 0.63 & 5.22 & 10.7 & 39.6 & 4.43 & -0.01 & 102.4 \\
\hline San Francisco & 1.54 & 2.66 & 36.7 & 32.2 & 1.51 & -0.39 & 190.4 \\
\hline San Jose & 0.83 & 0.92 & 47.5 & 34.3 & 2.01 & -0.71 & 175.9 \\
\hline Seattle & 0.63 & 2.68 & 18.9 & 43.2 & 4.62 & 0.55 & 62.7 \\
\hline Washington, DC & 1.36 & 3.89 & 25.9 & 43.3 & 4.36 & 0.60 & 68.9 \\
\hline All Educated & 6.60 & 25.47 & 20.6 & 38.5 & 3.05 & 0.03 & 95.4 \\
\hline \multicolumn{8}{|l|}{ Balanced } \\
\hline Bridgeport & 0.22 & 0.67 & 24.7 & 40.4 & 3.58 & -0.73 & 373.6 \\
\hline Chicago & 2.17 & 7.34 & 22.9 & 35.6 & 2.22 & 0.24 & 71.3 \\
\hline Hartford & 0.16 & 1.02 & 13.9 & 32.3 & 2.77 & 0.12 & 76.9 \\
\hline New York & 6.68 & 12.07 & 35.6 & 32.0 & 1.72 & -0.31 & 154.5 \\
\hline Portland & 0.34 & 1.85 & 15.7 & 37.7 & 4.21 & 1.36 & 34.1 \\
\hline Providence & 0.26 & 1.33 & 16.1 & 27.1 & 1.87 & -0.16 & 192.4 \\
\hline Sacramento & 0.47 & 1.62 & 22.6 & 33.0 & 5.03 & 1.40 & 47.8 \\
\hline Tampa & 0.40 & 2.32 & 14.8 & 38.4 & 5.64 & 1.36 & 38.0 \\
\hline All Balanced & 10.72 & 28.23 & 27.5 & 33.2 & 2.21 & 0.18 & 81.6 \\
\hline
\end{tabular}

Source: Authors' calculations using the 2000 IPUMS and the 2007 ACS

Note: Two versions of the national population numbers are provided, varying according to whether children are classified according to their parentage or according to their nativity. At the metropolitan level, we classify children according to their parentage. See text for details. Averages are population weighted. Population growth data for 2007 refer to the period 2000-2007, and for 2000 refer to the period 1990-2000.

Corresponds to Figure 1. 
Appendix Table 2

Nativity of School-Age Children

\begin{tabular}{|c|c|c|c|c|c|}
\hline \multirow[b]{2}{*}{ Year/Location } & \multicolumn{2}{|c|}{ Natives } & \multirow[b]{2}{*}{ Immigrants } & \multirow{2}{*}{$\begin{array}{c}\text { (1) } /[(1)+(2)] \\
\text { Children of } \\
\text { Immigrants as } \\
\text { Share of Natives }\end{array}$} & \multirow{2}{*}{$\begin{array}{c}{[(1)+(3)] /} \\
{[(1)+(2)+(3)]} \\
\\
\text { Children of } \\
\text { Immigrants } \\
\text { and } \\
\text { Immigrants as } \\
\text { Share of Total }\end{array}$} \\
\hline & $\begin{array}{l}\text { Children of } \\
\text { Immigrants }\end{array}$ & $\begin{array}{c}\text { Children of } \\
\text { Natives }\end{array}$ & & & \\
\hline Full U.S. 2007 & 12.1 & 82.4 & 5.5 & 12.8 & 17.6 \\
\hline 42 Metros 2007 & 20.4 & 71.2 & 8.4 & 22.2 & 28.8 \\
\hline Full U.S. 2000 & 9.2 & 85.0 & 5.8 & 9.8 & 15.0 \\
\hline \multicolumn{6}{|l|}{ New } \\
\hline Atlanta & 9.7 & 83.8 & 6.5 & 10.3 & 16.2 \\
\hline Austin & 12.7 & 80.2 & 7.2 & 13.6 & 19.8 \\
\hline Charlotte & 5.8 & 88.5 & 5.7 & 6.1 & 11.5 \\
\hline Dallas & 18.7 & 72.9 & 8.4 & 20.4 & 27.1 \\
\hline Denver & 11.7 & 81.4 & 7.0 & 12.5 & 18.6 \\
\hline Minneapolis & 6.9 & 86.6 & 6.5 & 7.4 & 13.4 \\
\hline Orlando & 14.1 & 79.5 & 6.4 & 15.1 & 20.5 \\
\hline Phoenix & 18.5 & 72.1 & 9.4 & 20.4 & 27.9 \\
\hline Raleigh-Durham & 7.7 & 85.3 & 7.0 & 8.3 & 14.7 \\
\hline Salt Lake City & 9.7 & 83.1 & 7.2 & 10.4 & 16.9 \\
\hline All New & 12.9 & 79.7 & 7.4 & 14.0 & 20.3 \\
\hline \multicolumn{6}{|l|}{ Hispanic } \\
\hline Bakersfield & 27.3 & 64.3 & 8.4 & 29.8 & 35.7 \\
\hline El Paso & 29.2 & 63.8 & 7.0 & 31.4 & 36.2 \\
\hline Fresno & 29.0 & 62.2 & 8.8 & 31.8 & 37.8 \\
\hline Houston & 22.1 & 67.7 & 10.2 & 24.7 & 32.3 \\
\hline Las Vegas & 22.3 & 67.5 & 10.1 & 24.9 & 32.5 \\
\hline Los Angeles & 42.2 & 46.9 & 10.9 & 47.3 & 53.1 \\
\hline McAllen & 31.9 & 55.8 & 12.3 & 36.3 & 44.2 \\
\hline Miami & 29.8 & 54.9 & 15.2 & 35.2 & 45.1 \\
\hline Oxnard & 25.1 & 66.7 & 8.2 & 27.4 & 33.3 \\
\hline Riverside & 29.8 & 62.9 & 7.3 & 32.1 & 37.1 \\
\hline Salinas & 36.6 & 53.0 & 10.3 & 40.8 & 47.0 \\
\hline San Antonio & 10.2 & 85.7 & 4.1 & 10.6 & 14.3 \\
\hline San Diego & 24.3 & 66.6 & 9.1 & 26.7 & 33.4 \\
\hline Stockton & 27.0 & 63.4 & 9.6 & 29.8 & 36.6 \\
\hline Tucscon & 13.9 & 78.2 & 7.9 & 15.1 & 21.8 \\
\hline Visalia & 34.0 & 55.7 & 10.2 & 37.9 & 44.3 \\
\hline All Hispanic & 30.6 & 59.3 & 10.1 & 34.0 & 40.7 \\
\hline \multicolumn{6}{|l|}{ Educated } \\
\hline Baltimore & 4.6 & 91.0 & 4.3 & 4.9 & 9.0 \\
\hline Boston & 11.4 & 81.8 & 6.8 & 12.2 & 18.2 \\
\hline Detroit & 7.0 & 89.2 & 3.8 & 7.3 & 10.8 \\
\hline Philadelphia & 6.1 & 89.9 & 4.0 & 6.4 & 10.1 \\
\hline San Francisco & 28.9 & 60.7 & 10.4 & 32.2 & 39.3 \\
\hline San Jose & 34.6 & 50.2 & 15.2 & 40.8 & 49.8 \\
\hline Seattle & 11.7 & 79.7 & 8.5 & 12.8 & 20.3 \\
\hline Washington, DC & 16.5 & 74.0 & 9.5 & 18.3 & 26.0 \\
\hline All Educated & 13.3 & 79.6 & 7.1 & 14.4 & 20.4 \\
\hline \multicolumn{6}{|l|}{ Balanced } \\
\hline Bridgeport & 14.8 & 79.8 & 5.5 & 15.6 & 20.2 \\
\hline Chicago & 17.1 & 76.3 & 6.6 & 18.3 & 23.7 \\
\hline Hartford & 6.9 & 88.2 & 4.9 & 7.3 & 11.8 \\
\hline New York & 26.1 & 63.7 & 10.2 & 29.1 & 36.3 \\
\hline Portland & 12.4 & 80.5 & 7.1 & 13.4 & 19.5 \\
\hline Providence & 13.6 & 81.9 & 4.5 & 14.3 & 18.1 \\
\hline Sacramento & 18.5 & 73.7 & 7.8 & 20.1 & 26.3 \\
\hline Tampa & 9.8 & 85.1 & 5.1 & 10.3 & 14.9 \\
\hline All Balanced & 20.2 & 71.7 & 8.1 & 22.0 & 28.3 \\
\hline
\end{tabular}

Source: Authors' calculations using the 2000 IPUMS and 2007 ACS.

Note: See text for defintion of native children of immigrants. Averages are population weighted.

Columns 1, 2, and 3 sum to 100.

Corresponds to Figure 2. 
Appendix Table 3

Immigrant and Native Share of Overall Growth in School Age Population, 2000-2007

\begin{tabular}{|c|c|c|c|c|}
\hline \multirow[b]{2}{*}{$\begin{array}{l}\text { Metrotypel } \\
\text { Metropolitan Area }\end{array}$} & \multirow{2}{*}{$\begin{array}{c}\text { Total Percentage } \\
\text { Change in School } \\
\text { Age Population }\end{array}$} & \multicolumn{3}{|c|}{ Percentage Points Due to } \\
\hline & & Immigrant Children & $\begin{array}{c}\text { Native Children of } \\
\text { Immigrants }\end{array}$ & $\begin{array}{c}\begin{array}{c}\text { Native Children of } \\
\text { Natives }\end{array} \\
\end{array}$ \\
\hline Full U.S. 2000-2007 & 3.1 & -0.1 & 3.2 & 0.1 \\
\hline 42 Metros 2000-2007 & 5.8 & -0.9 & 5.0 & 1.7 \\
\hline \multicolumn{5}{|l|}{ New } \\
\hline Atlanta & 26.5 & 1.9 & 6.8 & 17.7 \\
\hline Austin & 22.2 & 1.0 & 6.5 & 14.7 \\
\hline Charlotte & 26.3 & 3.0 & 4.0 & 19.4 \\
\hline Dallas & 15.2 & 0.5 & 9.2 & 5.5 \\
\hline Denver & 7.0 & 0.0 & 5.4 & 1.6 \\
\hline Minneapolis & -0.7 & 0.2 & 2.3 & -3.1 \\
\hline Orlando & 14.7 & 1.1 & 6.5 & 7.1 \\
\hline Phoenix & 26.0 & 1.7 & 12.3 & 12.1 \\
\hline Raleigh-Durham & 31.8 & 3.2 & 6.4 & 22.2 \\
\hline Salt Lake City & 6.2 & 1.4 & 4.8 & -0.0 \\
\hline All New & 17.2 & 1.2 & 7.1 & 8.9 \\
\hline \multicolumn{5}{|l|}{ Hispanic } \\
\hline Bakersfield & 9.2 & -0.4 & 10.0 & -0.3 \\
\hline El Paso & 1.8 & -3.8 & -0.4 & 6.0 \\
\hline Fresno & 0.9 & -5.2 & 3.6 & 2.6 \\
\hline Houston & 13.2 & 1.1 & 8.1 & 4.0 \\
\hline Las Vegas & 37.2 & 3.9 & 14.6 & 18.7 \\
\hline Los Angeles & 0.0 & -5.1 & 4.1 & 1.1 \\
\hline McAllen & 19.0 & -1.3 & 5.9 & 14.5 \\
\hline Miami & 1.7 & -1.7 & 2.8 & 0.6 \\
\hline Oxnard & -2.4 & -1.7 & 2.2 & -3.0 \\
\hline Riverside & 15.7 & 0.1 & 12.2 & 3.4 \\
\hline Salinas & -8.3 & -4.9 & 1.2 & -4.6 \\
\hline San Antonio & 10.4 & -0.1 & 2.5 & 8.1 \\
\hline San Diego & 2.1 & -2.2 & 1.9 & 2.3 \\
\hline Stockton & 13.7 & 0.4 & 9.0 & 4.3 \\
\hline Tucscon & 8.1 & 1.5 & 3.0 & 3.6 \\
\hline Visalia & 3.8 & -2.4 & 9.6 & -3.4 \\
\hline All Hispanic & 6.3 & -2.1 & 5.5 & 2.9 \\
\hline \multicolumn{5}{|l|}{ Educated } \\
\hline Baltimore & -0.7 & 1.4 & 1.3 & -3.4 \\
\hline Boston & 1.5 & 0.3 & 1.6 & -0.3 \\
\hline Detroit & -1.4 & -0.2 & 2.3 & -3.5 \\
\hline Philadelphia & -1.6 & 0.4 & 2.1 & -4.1 \\
\hline San Francisco & -3.7 & -2.6 & 3.6 & -4.8 \\
\hline San Jose & -0.1 & -1.9 & 5.3 & -3.5 \\
\hline Seattle & 1.7 & 1.4 & 4.5 & -4.2 \\
\hline Washington, DC & 6.8 & 1.0 & 5.4 & 0.4 \\
\hline All Educated & 0.4 & 0.1 & 3.1 & -2.8 \\
\hline \multicolumn{5}{|l|}{ Balanced } \\
\hline Bridgeport & 2.0 & -2.8 & 4.8 & -0.0 \\
\hline Chicago & 2.6 & -1.4 & 4.3 & -0.3 \\
\hline Hartford & -0.7 & -0.1 & 0.8 & -1.3 \\
\hline New York & 0.4 & -2.7 & 5.0 & -1.9 \\
\hline Portland & 6.3 & -0.3 & 6.6 & -0.0 \\
\hline Providence & -5.0 & -0.5 & 1.6 & -6.1 \\
\hline Sacramento & 5.3 & -0.7 & 6.9 & -0.9 \\
\hline Tampa & 13.4 & 1.0 & 4.6 & 7.8 \\
\hline All Balanced & 2.1 & -1.7 & 4.7 & -0.9 \\
\hline
\end{tabular}

Source: Authors' calculations using the 2000 IPUMS and 2007 ACS

Note: See text for defintion of native children of immigrants. Averages are population weighted.

Corresponds to Figure 2. 
Appendix Table 4

Male Share of the Working Age Population

\begin{tabular}{|c|c|c|c|}
\hline $\begin{array}{l}\text { Metrotype/ } \\
\text { Metropolitan Area } \\
\end{array}$ & Recent Immigrants & All Immigrants & Natives \\
\hline Full U.S. 2007 & 52.8 & 51.6 & 49.6 \\
\hline 42 Metros 2007 & 52.3 & 51.3 & 49.3 \\
\hline Full U.S. 2000 & 51.6 & 50.8 & 49.5 \\
\hline \multicolumn{4}{|l|}{ New } \\
\hline Atlanta & 58.7 & 56.6 & 48.2 \\
\hline Austin & 60.5 & 57.8 & 50.7 \\
\hline Charlotte & 58.9 & 57.5 & 48.3 \\
\hline Dallas & 58.5 & 56.5 & 49.2 \\
\hline Denver & 52.4 & 54.1 & 50.4 \\
\hline Minneapolis & 50.7 & 51.7 & 50.2 \\
\hline Orlando & 55.5 & 51.5 & 49.6 \\
\hline Phoenix & 58.2 & 55.4 & 49.9 \\
\hline Raleigh-Durham & 60.1 & 62.8 & 47.6 \\
\hline Salt Lake City & 53.6 & 53.4 & 51.2 \\
\hline All New & 57.5 & 55.6 & 49.4 \\
\hline \multicolumn{4}{|l|}{ Hispanic } \\
\hline Bakersfield & 56.1 & 55.1 & 52.9 \\
\hline El Paso & 39.5 & 43.0 & 50.4 \\
\hline Fresno & 52.7 & 54.1 & 50.4 \\
\hline Houston & 54.8 & 53.9 & 49.0 \\
\hline Las Vegas & 53.0 & 52.5 & 50.8 \\
\hline Los Angeles & 51.2 & 50.6 & 50.0 \\
\hline McAllen & 48.5 & 45.6 & 49.9 \\
\hline Miami & 50.4 & 48.9 & 49.2 \\
\hline Oxnard & 50.5 & 50.3 & 51.1 \\
\hline Riverside & 52.7 & 51.9 & 50.0 \\
\hline Salinas & 58.8 & 55.3 & 53.0 \\
\hline San Antonio & 56.1 & 51.2 & 49.3 \\
\hline San Diego & 46.5 & 47.9 & 52.1 \\
\hline Stockton & 54.2 & 52.2 & 50.3 \\
\hline Tucscon & 48.8 & 49.5 & 49.2 \\
\hline Visalia & 57.5 & 54.7 & 49.3 \\
\hline All Hispanic & 51.6 & 50.7 & 50.1 \\
\hline \multicolumn{4}{|l|}{ Educated } \\
\hline Baltimore & 48.7 & 46.5 & 48.5 \\
\hline Boston & 50.7 & 51.9 & 48.8 \\
\hline Detroit & 51.8 & 48.5 & 49.1 \\
\hline Philadelphia & 50.1 & 50.2 & 48.6 \\
\hline San Francisco & 50.8 & 51.6 & 50.3 \\
\hline San Jose & 51.6 & 50.9 & 52.7 \\
\hline Seattle & 49.2 & 49.1 & 50.8 \\
\hline Washington, DC & 50.0 & 51.7 & 48.4 \\
\hline All Educated & 50.8 & 50.5 & 49.3 \\
\hline \multicolumn{4}{|l|}{ Balanced } \\
\hline Bridgeport & 54.2 & 52.5 & 48.3 \\
\hline Chicago & 52.1 & 53.5 & 48.8 \\
\hline Hartford & 48.5 & 48.6 & 49.2 \\
\hline New York & 50.4 & 49.6 & 48.4 \\
\hline Portland & 47.6 & 50.7 & 50.2 \\
\hline Providence & 49.6 & 49.7 & 48.9 \\
\hline Sacramento & 47.9 & 51.0 & 49.3 \\
\hline Tampa & 52.2 & 50.5 & 49.2 \\
\hline All Balanced & 50.7 & 50.5 & 48.8 \\
\hline
\end{tabular}

Source: Authors' calculations using the 2000 IPUMS and 2007 ACS.

Note: Averages are population weighted.

Corresponds to Figure 3. 
Appendix Table 5

Average Age of Immigrants and Natives

\begin{tabular}{|c|c|c|c|}
\hline $\begin{array}{l}\text { Metrotype/ } \\
\text { Metropolitan Area }\end{array}$ & Recent Immigrants & All Immigrants & Natives \\
\hline Full U.S. 2007 & 26.0 & 34.1 & 37.3 \\
\hline 42 Metros 2007 & 26.4 & 34.2 & 36.6 \\
\hline Full U.S. 2000 & 25.2 & 35.8 & 36.3 \\
\hline \multicolumn{4}{|l|}{ New } \\
\hline Atlanta & 24.9 & 30.4 & 34.9 \\
\hline Austin & 24.4 & 30.0 & 33.9 \\
\hline Charlotte & 24.6 & 29.3 & 35.8 \\
\hline Dallas & 23.5 & 28.9 & 34.9 \\
\hline Denver & 24.2 & 30.6 & 36.4 \\
\hline Minneapolis & 24.3 & 29.1 & 36.8 \\
\hline Orlando & 28.0 & 35.2 & 37.4 \\
\hline Phoenix & 24.4 & 29.6 & 36.9 \\
\hline Raleigh-Durham & 25.2 & 29.3 & 35.5 \\
\hline Salt Lake City & 23.7 & 29.6 & 33.3 \\
\hline All New & 24.5 & 30.0 & 35.7 \\
\hline \multicolumn{4}{|l|}{ Hispanic } \\
\hline Bakersfield & 23.2 & 29.4 & 33.3 \\
\hline El Paso & 24.2 & 36.0 & 30.9 \\
\hline Fresno & 23.4 & 30.4 & 34.2 \\
\hline Houston & 24.8 & 30.6 & 34.7 \\
\hline Las Vegas & 24.6 & 32.0 & 36.4 \\
\hline Los Angeles & 26.8 & 34.3 & 35.9 \\
\hline McAllen & 22.3 & 31.0 & 30.0 \\
\hline Miami & 30.4 & 39.7 & 39.1 \\
\hline Oxnard & 25.4 & 33.5 & 36.6 \\
\hline Riverside & 23.9 & 31.2 & 34.0 \\
\hline Salinas & 24.3 & 31.2 & 36.5 \\
\hline San Antonio & 23.9 & 34.9 & 34.5 \\
\hline San Diego & 25.3 & 34.7 & 35.5 \\
\hline Stockton & 22.7 & 30.4 & 35.0 \\
\hline Tucscon & 25.6 & 34.7 & 38.5 \\
\hline Visalia & 21.4 & 27.2 & 35.0 \\
\hline All Hispanic & 26.3 & 34.1 & 35.6 \\
\hline \multicolumn{4}{|l|}{ Educated } \\
\hline Baltimore & 27.5 & 36.2 & 37.1 \\
\hline Boston & 27.8 & 35.8 & 38.3 \\
\hline Detroit & 26.9 & 36.4 & 37.4 \\
\hline Philadelphia & 26.5 & 35.7 & 37.6 \\
\hline San Francisco & 28.7 & 37.2 & 38.5 \\
\hline San Jose & 26.7 & 34.7 & 37.2 \\
\hline Seattle & 26.8 & 34.4 & 37.3 \\
\hline Washington, DC & 26.9 & 33.6 & 36.8 \\
\hline All Educated & 27.3 & 35.4 & 37.5 \\
\hline \multicolumn{4}{|l|}{ Balanced } \\
\hline Bridgeport & 26.7 & 35.5 & 38.8 \\
\hline Chicago & 25.3 & 33.7 & 36.2 \\
\hline Hartford & 27.7 & 38.3 & 38.3 \\
\hline New York & 27.8 & 36.7 & 37.8 \\
\hline Portland & 26.0 & 32.4 & 37.3 \\
\hline Providence & 25.2 & 37.2 & 38.4 \\
\hline Sacramento & 26.1 & 33.5 & 36.5 \\
\hline Tampa & 29.4 & 38.4 & 40.5 \\
\hline All Balanced & 27.1 & 35.9 & 37.6 \\
\hline
\end{tabular}

Source: Authors' calculations using the 2000 IPUMS and 2007 ACS.

Note: Immigrant populations include children of immigrants. See text for details.

Averages are population weighted.

Corresponds to Figure 4. 
Appendix Table 6

Percentage of the Population that Is Working Age (18-65)

\begin{tabular}{|c|c|c|c|}
\hline $\begin{array}{l}\text { Metrotype/ } \\
\text { Metropolitan Area }\end{array}$ & Recent Immigrants & All Immigrants & Natives \\
\hline Full U.S. 2007 & 65.3 & 64.2 & 63.7 \\
\hline 42 Metros 2007 & 65.1 & 64.2 & 64.3 \\
\hline Full U.S. 2000 & 63.9 & 64.0 & 62.4 \\
\hline \multicolumn{4}{|l|}{ New } \\
\hline Atlanta & 63.9 & 66.4 & 65.6 \\
\hline Austin & 67.7 & 67.2 & 67.3 \\
\hline Charlotte & 64.2 & 64.9 & 65.1 \\
\hline Dallas & 62.6 & 64.0 & 64.7 \\
\hline Denver & 64.2 & 64.2 & 66.4 \\
\hline Minneapolis & 61.0 & 62.7 & 65.9 \\
\hline Orlando & 71.3 & 67.5 & 63.5 \\
\hline Phoenix & 62.5 & 61.6 & 62.3 \\
\hline Raleigh-Durham & 67.2 & 67.6 & 67.0 \\
\hline Salt Lake City & 59.2 & 61.3 & 62.8 \\
\hline All New & 63.9 & 64.4 & 65.0 \\
\hline \multicolumn{4}{|l|}{ Hispanic } \\
\hline Bakersfield & 61.8 & 60.5 & 63.1 \\
\hline El Paso & 51.8 & 58.9 & 58.0 \\
\hline Fresno & 60.8 & 61.1 & 61.2 \\
\hline Houston & 62.0 & 63.9 & 64.4 \\
\hline Las Vegas & 63.7 & 64.7 & 63.8 \\
\hline Los Angeles & 64.4 & 62.7 & 65.3 \\
\hline McAllen & 51.2 & 56.7 & 54.4 \\
\hline Miami & 67.9 & 63.7 & 60.7 \\
\hline Oxnard & 64.0 & 63.8 & 63.3 \\
\hline Riverside & 60.9 & 61.2 & 62.2 \\
\hline Salinas & 67.2 & 63.4 & 64.6 \\
\hline San Antonio & 65.3 & 65.6 & 62.0 \\
\hline San Diego & 60.4 & 62.9 & 65.3 \\
\hline Stockton & 61.0 & 60.1 & 62.5 \\
\hline Tucscon & 58.8 & 61.1 & 62.5 \\
\hline Visalia & 58.9 & 56.8 & 61.1 \\
\hline All Hispanic & 63.5 & 62.7 & 63.3 \\
\hline \multicolumn{4}{|l|}{ Educated } \\
\hline Baltimore & 66.0 & 67.7 & 64.3 \\
\hline Boston & 67.6 & 70.5 & 65.5 \\
\hline Detroit & 62.8 & 64.6 & 63.6 \\
\hline Philadelphia & 65.0 & 66.7 & 63.4 \\
\hline San Francisco & 66.2 & 67.7 & 67.1 \\
\hline San Jose & 65.8 & 65.4 & 65.9 \\
\hline Seattle & 65.8 & 65.6 & 67.5 \\
\hline Washington, DC & 67.2 & 67.2 & 66.3 \\
\hline All Educated & 67.2 & 66.1 & 65.2 \\
\hline \multicolumn{4}{|l|}{ Balanced } \\
\hline Bridgeport & 71.2 & 68.5 & 61.2 \\
\hline Chicago & 64.2 & 64.2 & 63.8 \\
\hline Hartford & 70.7 & 65.6 & 64.2 \\
\hline New York & 67.7 & 65.5 & 64.1 \\
\hline Portland & 61.6 & 63.3 & 66.8 \\
\hline Providence & 63.8 & 65.7 & 64.6 \\
\hline Sacramento & 62.3 & 62.0 & 65.2 \\
\hline Tampa & 69.5 & 63.8 & 61.7 \\
\hline All Balanced & 66.6 & 65.0 & 64.0 \\
\hline
\end{tabular}

Source: Authors' calculations using the 2000 IPUMS and 2007 ACS.

Note: Immigrant populations include children of immigrants. See text for details.

Averages are population weighted.

Corresponds to Figure 5. 
Appendix Table 7

Years of Education of the Working Age Population

\begin{tabular}{|c|c|c|c|}
\hline $\begin{array}{l}\text { Metrotypel } \\
\text { Metropolitan Area }\end{array}$ & Recent Immigrants & All Immigrants & Natives \\
\hline Full U.S. 2007 & 12.0 & 12.0 & 13.4 \\
\hline 42 Metros 2007 & 12.0 & 12.1 & 13.7 \\
\hline Full U.S. 2000 & 11.5 & 11.6 & 13.2 \\
\hline \multicolumn{4}{|l|}{ New } \\
\hline Atlanta & 12.0 & 12.4 & 13.7 \\
\hline Austin & 11.5 & 11.3 & 13.8 \\
\hline Charlotte & 11.7 & 12.1 & 13.6 \\
\hline Dallas & 11.1 & 11.0 & 13.6 \\
\hline Denver & 11.5 & 11.6 & 14.0 \\
\hline Minneapolis & 12.1 & 12.2 & 14.0 \\
\hline Orlando & 12.2 & 12.7 & 13.4 \\
\hline Phoenix & 10.6 & 10.9 & 13.5 \\
\hline Raleigh-Durham & 12.2 & 12.5 & 14.1 \\
\hline Salt Lake City & 11.8 & 11.9 & 13.6 \\
\hline All New & 11.5 & 11.6 & 13.7 \\
\hline \multicolumn{4}{|l|}{ Hispanic } \\
\hline Bakersfield & 9.7 & 9.9 & 12.6 \\
\hline El Paso & 11.8 & 10.9 & 13.1 \\
\hline Fresno & 8.9 & 9.4 & 13.0 \\
\hline Houston & 11.1 & 11.1 & 13.3 \\
\hline Las Vegas & 11.2 & 11.4 & 13.2 \\
\hline Los Angeles & 11.7 & 11.5 & 13.7 \\
\hline McAllen & 10.0 & 9.7 & 12.4 \\
\hline Miami & 12.6 & 12.7 & 13.6 \\
\hline Oxnard & 11.3 & 11.1 & 13.8 \\
\hline Riverside & 10.9 & 11.0 & 13.1 \\
\hline Salinas & 8.0 & 8.9 & 13.4 \\
\hline San Antonio & 11.5 & 11.1 & 13.1 \\
\hline San Diego & 12.4 & 12.0 & 13.8 \\
\hline Stockton & 10.4 & 10.8 & 13.0 \\
\hline Tucscon & 12.2 & 12.2 & 13.5 \\
\hline Visalia & 8.3 & 8.5 & 12.7 \\
\hline All Hispanic & 11.5 & 11.4 & 13.4 \\
\hline \multicolumn{4}{|l|}{ Educated } \\
\hline Baltimore & 13.6 & 13.9 & 13.6 \\
\hline Boston & 13.2 & 13.2 & 14.2 \\
\hline Detroit & 13.3 & 13.1 & 13.4 \\
\hline Philadelphia & 12.9 & 13.3 & 13.5 \\
\hline San Francisco & 12.6 & 12.9 & 14.3 \\
\hline San Jose & 13.4 & 13.4 & 14.1 \\
\hline Seattle & 13.1 & 13.2 & 13.9 \\
\hline Washington, DC & 12.7 & 13.1 & 14.5 \\
\hline All Educated & 13.0 & 13.2 & 13.9 \\
\hline \multicolumn{4}{|l|}{ Balanced } \\
\hline Bridgeport & 12.5 & 12.9 & 14.3 \\
\hline Chicago & 12.3 & 12.1 & 13.8 \\
\hline Hartford & 13.3 & 13.3 & 13.8 \\
\hline New York & 12.5 & 12.7 & 13.9 \\
\hline Portland & 12.0 & 12.0 & 13.8 \\
\hline Providence & 11.9 & 11.2 & 13.4 \\
\hline Sacramento & 12.2 & 11.8 & 13.6 \\
\hline Tampa & 12.3 & 12.8 & 13.4 \\
\hline All Balanced & 12.4 & 12.5 & 13.8 \\
\hline
\end{tabular}

Source: Authors' calculations using the 2000 IPUM and the 2007 ACS.

Note: Averages are population weighted.

Corresponds to Figure 6 and Figure 9. 
Appendix Table 8

Dropout and College Graduate Share of the Working Age Population

\begin{tabular}{|c|c|c|c|c|c|c|}
\hline \multirow[b]{2}{*}{$\begin{array}{l}\text { Metrotype/ } \\
\text { Metropolitan Area }\end{array}$} & \multicolumn{3}{|c|}{ Dropout Share } & \multicolumn{3}{|c|}{ College Graduate Share } \\
\hline & $\begin{array}{c}\text { Recent } \\
\text { Immigrants } \\
\end{array}$ & $\begin{array}{c}\text { All } \\
\text { Immigrants } \\
\end{array}$ & Natives & $\begin{array}{c}\text { Recent } \\
\text { Immigrants } \\
\end{array}$ & $\begin{array}{c}\text { All } \\
\text { Immigrants } \\
\end{array}$ & Natives \\
\hline Full U.S. 2007 & 31.4 & 30.2 & 10.5 & 26.4 & 25.9 & 26.2 \\
\hline 42 Metros 2007 & 30.6 & 29.6 & 9.0 & 27.1 & 26.6 & 32.2 \\
\hline Full U.S. 2000 & 39.7 & 37.6 & 14.3 & 23.2 & 22.6 & 23.7 \\
\hline \multicolumn{7}{|l|}{ New } \\
\hline Atlanta & 30.5 & 26.2 & 10.0 & 26.5 & 30.8 & 33.1 \\
\hline Austin & 39.3 & 41.8 & 8.5 & 25.3 & 25.0 & 35.7 \\
\hline Charlotte & 35.3 & 30.0 & 9.9 & 24.4 & 27.5 & 32.2 \\
\hline Dallas & 43.7 & 43.1 & 9.7 & 21.3 & 20.3 & 30.3 \\
\hline Denver & 35.3 & 35.6 & 7.1 & 21.9 & 23.4 & 37.1 \\
\hline Minneapolis & 28.2 & 26.4 & 4.9 & 30.6 & 30.4 & 35.8 \\
\hline Orlando & 25.4 & 20.8 & 10.8 & 25.2 & 26.6 & 26.4 \\
\hline Phoenix & 48.7 & 43.8 & 9.5 & 15.8 & 15.7 & 26.8 \\
\hline Raleigh-Durham & 30.9 & 32.3 & 7.0 & 34.2 & 35.9 & 40.8 \\
\hline Salt Lake City & 31.0 & 30.4 & 7.9 & 21.4 & 21.1 & 27.6 \\
\hline All New & 37.6 & 35.6 & 8.7 & 23.3 & 23.8 & 32.3 \\
\hline \multicolumn{7}{|l|}{ Hispanic } \\
\hline Bakersfield & 55.1 & 52.0 & 18.5 & 8.6 & 8.6 & 13.8 \\
\hline El Paso & 34.4 & 42.7 & 13.4 & 21.1 & 13.4 & 20.5 \\
\hline Fresno & 61.4 & 53.6 & 12.3 & 11.3 & 11.5 & 18.4 \\
\hline Houston & 42.4 & 41.5 & 12.0 & 21.3 & 20.5 & 27.2 \\
\hline Las Vegas & 38.5 & 35.4 & 9.9 & 16.7 & 16.9 & 20.9 \\
\hline Los Angeles & 34.9 & 35.9 & 9.2 & 24.7 & 22.6 & 31.8 \\
\hline McAllen & 51.9 & 54.9 & 20.4 & 11.2 & 9.8 & 16.8 \\
\hline Miami & 21.6 & 20.6 & 9.9 & 26.1 & 25.2 & 29.6 \\
\hline Oxnard & 44.9 & 42.6 & 6.9 & 20.9 & 21.8 & 31.0 \\
\hline Riverside & 43.2 & 40.9 & 11.9 & 14.6 & 14.1 & 17.6 \\
\hline Salinas & 65.9 & 59.5 & 11.4 & 10.2 & 8.8 & 25.1 \\
\hline San Antonio & 36.2 & 37.5 & 13.1 & 18.5 & 15.2 & 23.0 \\
\hline San Diego & 30.5 & 30.8 & 6.9 & 30.4 & 25.2 & 32.3 \\
\hline Stockton & 46.6 & 40.8 & 13.3 & 14.0 & 14.6 & 16.1 \\
\hline Tucscon & 31.9 & 29.2 & 8.1 & 24.6 & 22.9 & 26.9 \\
\hline Visalia & 66.9 & 63.2 & 17.3 & 1.6 & 4.4 & 13.8 \\
\hline All Hispanic & 36.0 & 35.8 & 10.7 & 22.2 & 20.6 & 26.5 \\
\hline \multicolumn{7}{|l|}{ Educated } \\
\hline Baltimore & 14.9 & 17.3 & 10.5 & 41.5 & 43.5 & 31.7 \\
\hline Boston & 19.6 & 18.4 & 5.7 & 37.9 & 37.6 & 42.5 \\
\hline Detroit & 21.2 & 20.4 & 9.9 & 41.8 & 38.3 & 24.3 \\
\hline Philadelphia & 19.6 & 24.4 & 9.3 & 35.4 & 38.0 & 29.3 \\
\hline San Francisco & 22.0 & 26.3 & 5.8 & 33.7 & 36.1 & 43.9 \\
\hline San Jose & 20.0 & 24.1 & 7.0 & 47.0 & 44.1 & 39.0 \\
\hline Seattle & 17.9 & 20.1 & 6.4 & 35.8 & 33.8 & 33.8 \\
\hline Washington, DC & 20.5 & 23.8 & 6.1 & 34.7 & 39.3 & 46.7 \\
\hline All Educated & 22.7 & 20.2 & 7.7 & 37.3 & 38.4 & 35.8 \\
\hline \multicolumn{7}{|l|}{ Balanced } \\
\hline Bridgeport & 22.9 & 21.2 & 6.2 & 29.0 & 31.3 & 43.9 \\
\hline Chicago & 26.0 & 28.6 & 8.4 & 26.6 & 25.6 & 33.3 \\
\hline Hartford & 16.9 & 15.9 & 8.3 & 31.8 & 30.1 & 34.0 \\
\hline New York & 24.5 & 21.9 & 9.1 & 29.2 & 30.2 & 37.0 \\
\hline Portland & 31.8 & 29.7 & 6.8 & 25.8 & 25.1 & 32.4 \\
\hline Providence & 31.0 & 35.8 & 10.1 & 28.3 & 19.7 & 29.2 \\
\hline Sacramento & 27.6 & 28.7 & 7.7 & 26.2 & 23.8 & 28.3 \\
\hline Tampa & 26.1 & 21.3 & 10.2 & 22.6 & 26.9 & 25.7 \\
\hline All Balanced & 25.2 & 24.0 & 8.7 & 28.2 & 28.5 & 34.0 \\
\hline
\end{tabular}

Source: Authors' calculations using the 2000 IPUMS and 2007 ACS. Note: Averages are population weighted.

Corresponds to Figures 7 and 8. 
Appendix Table 9

Share of Working-Age Immigrants Who Are Proficient in English, Hispanic, and Mexican

\begin{tabular}{|c|c|c|c|c|c|c|}
\hline \multirow{2}{*}{$\begin{array}{l}\text { Metrotype/ } \\
\text { Metropolitan Area }\end{array}$} & \multicolumn{2}{|c|}{ Proficient in English } & \multicolumn{2}{|c|}{ Hispanic } & \multicolumn{2}{|c|}{ Mexican } \\
\hline & Recent & Immigrants & Recent & Immigrants & Recent & Immigrants \\
\hline Full U.S. 2007 & 34.9 & 46.5 & 51.3 & 49.4 & 34.3 & 32.5 \\
\hline 42 Metros 2007 & 36.1 & 47.3 & 51.0 & 49.6 & 32.1 & 30.9 \\
\hline Full U.S. 2000 & 36.8 & 48.3 & 48.8 & 46.9 & 33.0 & 30.1 \\
\hline \multicolumn{7}{|l|}{ New } \\
\hline Atlanta & 36.5 & 48.6 & 52.7 & 42.7 & 34.9 & 26.7 \\
\hline Austin & 33.6 & 41.7 & 65.8 & 65.3 & 58.5 & 57.8 \\
\hline Charlotte & 35.6 & 45.4 & 64.2 & 54.2 & 41.0 & 30.6 \\
\hline Dallas & 27.4 & 36.4 & 68.4 & 67.5 & 58.9 & 58.5 \\
\hline Denver & 29.0 & 40.0 & 64.8 & 58.8 & 56.7 & 51.9 \\
\hline Minneapolis & 45.1 & 52.6 & 26.0 & 23.1 & 20.4 & 18.2 \\
\hline Orlando & 39.2 & 53.7 & 51.0 & 45.7 & 18.8 & 13.1 \\
\hline Phoenix & 23.4 & 35.7 & 75.5 & 72.3 & 70.2 & 66.4 \\
\hline Raleigh-Durham & 44.0 & 53.0 & 51.7 & 47.2 & 39.2 & 33.2 \\
\hline Salt Lake City & 27.4 & 39.5 & 65.7 & 58.7 & 49.3 & 45.6 \\
\hline All New & 32.2 & 42.4 & 60.9 & 57.2 & 48.6 & 48.6 \\
\hline \multicolumn{7}{|l|}{ Hispanic } \\
\hline Bakersfield & 18.0 & 32.6 & 77.0 & 79.6 & 71.8 & 72.8 \\
\hline El Paso & 22.6 & 34.1 & 93.0 & 94.8 & 88.1 & 92.0 \\
\hline Fresno & 24.9 & 37.8 & 75.8 & 69.6 & 72.6 & 66.4 \\
\hline Houston & 27.7 & 37.9 & 68.5 & 68.6 & 47.3 & 49.3 \\
\hline Las Vegas & 29.0 & 42.9 & 64.8 & 61.5 & 53.6 & 47.8 \\
\hline Los Angeles & 26.8 & 38.8 & 55.9 & 59.6 & 40.3 & 43.7 \\
\hline McAllen & 18.9 & 28.9 & 94.0 & 95.9 & 89.0 & 92.9 \\
\hline Miami & 31.5 & 47.4 & 68.4 & 65.2 & 5.6 & 3.4 \\
\hline Oxnard & 30.0 & 42.0 & 69.3 & 68.2 & 64.7 & 62.2 \\
\hline Riverside & 23.3 & 39.5 & 76.9 & 75.9 & 70.0 & 66.7 \\
\hline Salinas & 15.7 & 25.8 & 84.2 & 82.0 & 81.8 & 79.7 \\
\hline San Antonio & 34.1 & 43.4 & 79.6 & 78.5 & 75.3 & 71.5 \\
\hline San Diego & 35.3 & 48.3 & 52.9 & 55.3 & 49.8 & 52.1 \\
\hline Stockton & 23.2 & 36.8 & 68.0 & 57.4 & 66.7 & 53.0 \\
\hline Tucscon & 30.3 & 44.7 & 71.8 & 69.2 & 66.8 & 63.3 \\
\hline Visalia & 8.2 & 22.1 & 92.5 & 87.7 & 91.8 & 86.7 \\
\hline All Hispanic & 27.6 & 40.3 & 65.4 & 65.5 & 43.2 & 44.8 \\
\hline \multicolumn{7}{|l|}{ Educated } \\
\hline Baltimore & 53.9 & 64.7 & 22.0 & 16.4 & 11.2 & 7.0 \\
\hline Boston & 48.3 & 56.2 & 23.0 & 22.1 & 3.1 & 2.2 \\
\hline Detroit & 46.1 & 58.1 & 18.4 & 14.7 & 13.9 & 10.2 \\
\hline Philadelphia & 44.0 & 55.1 & 27.5 & 19.9 & 17.0 & 9.7 \\
\hline San Francisco & 36.4 & 50.4 & 36.7 & 33.3 & 25.1 & 21.8 \\
\hline San Jose & 42.5 & 49.6 & 32.6 & 29.5 & 29.8 & 25.6 \\
\hline Seattle & 38.2 & 50.7 & 25.5 & 20.8 & 21.8 & 16.7 \\
\hline Washington, DC & 45.5 & 58.1 & 40.8 & 35.2 & 6.7 & 5.0 \\
\hline All Educated & 43.3 & 54.2 & 31.2 & 27.3 & 15.6 & 13.1 \\
\hline \multicolumn{7}{|l|}{ Balanced } \\
\hline Bridgeport & 42.8 & 54.1 & 38.7 & 33.9 & 6.0 & 6.7 \\
\hline Chicago & 31.3 & 41.8 & 47.6 & 50.3 & 43.4 & 41.2 \\
\hline Hartford & 56.2 & 65.3 & 22.6 & 16.7 & 1.1 & 1.1 \\
\hline New York & 40.7 & 52.3 & 38.4 & 35.0 & 6.6 & 10.6 \\
\hline Portland & 34.0 & 45.8 & 42.5 & 41.1 & 33.7 & 36.2 \\
\hline Providence & 35.7 & 48.4 & 44.0 & 31.3 & 2.3 & 4.2 \\
\hline Sacramento & 37.1 & 46.5 & 38.8 & 38.8 & 33.1 & 33.1 \\
\hline Tampa & 39.6 & 57.7 & 55.4 & 44.6 & 17.9 & 30.5 \\
\hline All Balanced & 38.5 & 50.1 & 41.1 & 38.4 & 19.3 & 16.1 \\
\hline
\end{tabular}

Source: Authors' calculations using the 2000 IPUMS and 2007 ACS.

Note: Averages are population weighted.

Corresponds to Figures 10 and 11. 
Appendix Table 10

Hourly Wages (2008\$)

\begin{tabular}{|c|c|c|c|}
\hline $\begin{array}{l}\text { Metrotype/ } \\
\text { Metropolitan Area }\end{array}$ & Recent Immigrants & All Immigrants & Natives \\
\hline Full U.S. 2007 & $\$ 16.84$ & $\$ 20.29$ & $\$ 22.05$ \\
\hline 42 Metros 2007 & $\$ 17.44$ & $\$ 20.95$ & $\$ 25.69$ \\
\hline Full U.S. 2000 & $\$ 17.95$ & $\$ 20.70$ & $\$ 21.67$ \\
\hline \multicolumn{4}{|l|}{ New } \\
\hline Atlanta & $\$ 16.46$ & $\$ 19.73$ & $\$ 24.12$ \\
\hline Austin & $\$ 17.55$ & $\$ 18.60$ & $\$ 22.34$ \\
\hline Charlotte & $\$ 15.25$ & $\$ 18.05$ & $\$ 22.92$ \\
\hline Dallas & $\$ 14.70$ & $\$ 17.16$ & $\$ 23.87$ \\
\hline Denver & $\$ 14.64$ & $\$ 17.75$ & $\$ 25.03$ \\
\hline Minneapolis & $\$ 17.65$ & $\$ 20.11$ & $\$ 25.53$ \\
\hline Orlando & $\$ 15.42$ & $\$ 18.76$ & $\$ 21.82$ \\
\hline Phoenix & $\$ 15.18$ & $\$ 17.28$ & $\$ 24.00$ \\
\hline Raleigh-Durham & $\$ 16.91$ & $\$ 20.18$ & $\$ 23.58$ \\
\hline Salt Lake City & $\$ 12.61$ & $\$ 16.19$ & $\$ 21.30$ \\
\hline All New & $\$ 15.63$ & $\$ 18.21$ & $\$ 23.85$ \\
\hline \multicolumn{4}{|l|}{ Hispanic } \\
\hline Bakersfield & $\$ 15.67$ & $\$ 15.67$ & $\$ 21.35$ \\
\hline El Paso & $\$ 12.16$ & $\$ 13.59$ & $\$ 16.96$ \\
\hline Fresno & $\$ 11.90$ & $\$ 14.89$ & $\$ 21.22$ \\
\hline Houston & $\$ 15.36$ & $\$ 18.09$ & $\$ 24.06$ \\
\hline Las Vegas & $\$ 15.18$ & $\$ 18.78$ & $\$ 23.67$ \\
\hline Los Angeles & $\$ 15.97$ & $\$ 19.89$ & $\$ 27.09$ \\
\hline McAllen & $\$ 9.85$ & $\$ 11.79$ & $\$ 15.19$ \\
\hline Miami & $\$ 15.42$ & $\$ 19.01$ & $\$ 24.36$ \\
\hline Oxnard & $\$ 14.86$ & $\$ 19.11$ & $\$ 27.75$ \\
\hline Riverside & $\$ 14.58$ & $\$ 18.69$ & $\$ 22.26$ \\
\hline Salinas & $\$ 12.60$ & $\$ 14.64$ & $\$ 23.81$ \\
\hline San Antonio & $\$ 17.11$ & $\$ 17.51$ & $\$ 19.23$ \\
\hline San Diego & $\$ 18.85$ & $\$ 20.97$ & $\$ 25.42$ \\
\hline Stockton & $\$ 14.87$ & $\$ 18.35$ & $\$ 24.23$ \\
\hline Tucscon & $\$ 13.82$ & $\$ 16.90$ & $\$ 20.44$ \\
\hline Visalia & $\$ 10.04$ & $\$ 12.63$ & $\$ 21.91$ \\
\hline All Hispanic & $\$ 15.44$ & $\$ 18.86$ & $\$ 24.11$ \\
\hline \multicolumn{4}{|l|}{ Educated } \\
\hline Baltimore & $\$ 20.61$ & $\$ 25.32$ & $\$ 25.76$ \\
\hline Boston & $\$ 20.02$ & $\$ 23.84$ & $\$ 28.31$ \\
\hline Detroit & $\$ 21.15$ & $\$ 25.14$ & $\$ 23.72$ \\
\hline Philadelphia & $\$ 18.94$ & $\$ 23.99$ & $\$ 25.08$ \\
\hline San Francisco & $\$ 20.98$ & $\$ 26.18$ & $\$ 33.02$ \\
\hline San Jose & $\$ 27.92$ & $\$ 31.95$ & $\$ 32.12$ \\
\hline Seattle & $\$ 21.55$ & $\$ 23.91$ & $\$ 25.98$ \\
\hline Washington, DC & $\$ 19.71$ & $\$ 24.62$ & $\$ 31.64$ \\
\hline All Educated & $\$ 21.11$ & $\$ 25.68$ & $\$ 27.68$ \\
\hline \multicolumn{4}{|l|}{ Balanced } \\
\hline Bridgeport & $\$ 20.21$ & $\$ 25.28$ & $\$ 34.69$ \\
\hline Chicago & $\$ 16.77$ & $\$ 20.26$ & $\$ 25.69$ \\
\hline Hartford & $\$ 17.91$ & $\$ 21.85$ & $\$ 25.30$ \\
\hline New York & $\$ 19.24$ & $\$ 22.88$ & $\$ 29.77$ \\
\hline Portland & $\$ 16.49$ & $\$ 18.98$ & $\$ 23.20$ \\
\hline Providence & $\$ 16.03$ & $\$ 18.87$ & $\$ 22.47$ \\
\hline Sacramento & $\$ 17.55$ & $\$ 21.02$ & $\$ 24.74$ \\
\hline Tampa & $\$ 15.32$ & $\$ 19.67$ & $\$ 21.61$ \\
\hline All Balanced & $\$ 18.30$ & $\$ 21.96$ & $\$ 26.87$ \\
\hline
\end{tabular}

Source: Authors' calculations using the 2000 IPUMS and 2007 ACS.

Note: Figures adjusted using for inflation using the CPI-U. Averages are population weighted.

Corresponds to Figure 12. 
Appendix Table 11

Unemployment Rates

Metrotype

Metropolitan Area

Recent Immigrants

All Immigrants

Natives

Full U.S. 2007

42 Metros 2007

Full U.S. 2000

6.2

6.1

5.4

6.1

7.9

6.7

5.2

New

Atlanta

Austin

Charlotte

6.1
5.4

Dallas

Denver

Minneapolis

Orlando

Phoenix

Raleigh-Durham

Salt Lake City

All New

8.2

4.2

3.8

7.7

5.9

4.8

4.4

5.3

5.3

$\begin{array}{ll}6.1 & 7.0 \\ 4.4 & 4.8 \\ 6.6 & 6.5 \\ 4.1 & 5.9 \\ 3.8 & 5.3 \\ 6.8 & 5.3 \\ 5.1 & 5.6 \\ 4.6 & 5.1 \\ 4.7 & 4.9 \\ 2.9 & 3.6 \\ \mathbf{4 . 9} & \mathbf{5 . 7}\end{array}$

Hispanic

Bakersfield 14.6

$11.5 \quad 8.3$

El Paso

Fresno

7.6

Houston

Las Vegas

Los Angeles

McAllen

Miami

Oxnard

Riverside

Salinas

San Antonio

San Diego

Stockton

Tucscon

Visalia

All Hispanic

\section{9}

5.9

6.3

5.9

9.1

6.0

5.6

8.4

8.3

3.0

5.5

7.4

8.0

8.8

6.4

$8.0 \quad 6.8$

$\begin{array}{ll}9.1 & 8.3\end{array}$

$\begin{array}{ll}4.7 & 5.9\end{array}$

$5.3 \quad 5.4$

$\begin{array}{ll}5.0 & 6.4\end{array}$

$\begin{array}{ll}9.6 & 7.5\end{array}$

4.8
4.5

$\begin{array}{ll}4.5 & 5.2\end{array}$

$\begin{array}{ll}6.7 & 7.7\end{array}$

$\begin{array}{ll}7.4 & 6.8\end{array}$

$\begin{array}{ll}2.7 & 5.8\end{array}$

$\begin{array}{ll}4.9 & 5.9\end{array}$

$\begin{array}{ll}8.2 & 9.1\end{array}$

$6.9 \quad 5.8$

6.9
12.1

Educated

Baltimore $\quad 4.0$

4.0
7.4

5.5

6.4

Boston

8.1

Detroit

Philadelphia

San Francisco

7.5

6.4

4.4

San Jose

Seattle

Washington, DC

4.9

5.1

All Educated

6.0

4.3

6.0

5.7

10.5

$6.1 \quad 6.2$

$5.0 \quad 5.6$

$4.3 \quad 5.9$

$4.0 \quad 4.8$

$4.2 \quad 4.6$

Balanced

Bridgeport 7.2

Chicago

Hartford

New York

Portland

Providence

Sacramento

Tampa

All Balanced

7.2

5.3

5.3

6.4

5.5

9.5

8.8

6.9

6.3

$\begin{array}{ll}5.3 & 5.1 \\ 5.1 & 7.4 \\ 4.8 & 5.7 \\ 5.2 & 6.2 \\ 4.8 & 5.8 \\ 7.8 & 5.6 \\ 6.8 & 6.6 \\ 6.5 & 6.1 \\ \mathbf{5 . 4} & \mathbf{6 . 4}\end{array}$

Source: Authors' calculations using the 2000 IPUMS and 2007 ACS.

Note: Averages are population weighted.

Corresponds to Figure $13 .$. 


\section{Appendix Table 12}

Poverty Rates

\begin{tabular}{|c|c|c|c|}
\hline $\begin{array}{l}\text { Metrotype/ } \\
\text { Metropolitan Area }\end{array}$ & Recent Immigrants & All Immigrants & Natives \\
\hline Full U.S. 2007 & 20.4 & 16.1 & 11.2 \\
\hline 42 Metros 2007 & 19.1 & 15.3 & 9.4 \\
\hline Full U.S. 2000 & 24.7 & 19.0 & 11.2 \\
\hline \multicolumn{4}{|l|}{ New } \\
\hline Atlanta & 17.9 & 14.2 & 9.5 \\
\hline Austin & 24.0 & 17.6 & 10.7 \\
\hline Charlotte & 21.0 & 16.9 & 9.7 \\
\hline Dallas & 22.3 & 19.3 & 9.8 \\
\hline Denver & 24.5 & 20.8 & 7.9 \\
\hline Minneapolis & 24.8 & 20.5 & 6.1 \\
\hline Orlando & 13.1 & 10.1 & 9.5 \\
\hline Phoenix & 24.2 & 21.2 & 8.9 \\
\hline Raleigh-Durham & 23.0 & 17.9 & 9.2 \\
\hline Salt Lake City & 19.8 & 17.2 & 6.6 \\
\hline All New & 21.6 & 18.0 & 8.9 \\
\hline \multicolumn{4}{|l|}{ Hispanic } \\
\hline Bakersfield & 30.3 & 23.7 & 14.4 \\
\hline El Paso & 51.7 & 40.1 & 22.8 \\
\hline Fresno & 33.5 & 26.1 & 14.5 \\
\hline Houston & 25.5 & 19.1 & 11.0 \\
\hline Las Vegas & 17.0 & 12.9 & 8.7 \\
\hline Los Angeles & 21.5 & 16.3 & 9.0 \\
\hline McAllen & 52.1 & 46.7 & 24.1 \\
\hline Miami & 18.0 & 14.0 & 10.2 \\
\hline Oxnard & 17.3 & 15.3 & 5.4 \\
\hline Riverside & 19.2 & 14.5 & 9.5 \\
\hline Salinas & 23.8 & 17.5 & 7.7 \\
\hline San Antonio & 23.8 & 20.7 & 13.3 \\
\hline San Diego & 19.5 & 15.4 & 7.8 \\
\hline Stockton & 22.4 & 19.1 & 10.3 \\
\hline Tucscon & 33.8 & 24.1 & 11.7 \\
\hline Visalia & 36.7 & 37.6 & 14.6 \\
\hline All Hispanic & 22.8 & 17.6 & 10.5 \\
\hline \multicolumn{4}{|l|}{ Educated } \\
\hline Baltimore & 10.9 & 7.7 & 8.8 \\
\hline Boston & 14.8 & 13.0 & 7.2 \\
\hline Detroit & 16.1 & 14.1 & 12.9 \\
\hline Philadelphia & 13.5 & 12.5 & 10.5 \\
\hline San Francisco & 14.4 & 9.9 & 7.5 \\
\hline San Jose & 12.7 & 9.3 & 6.6 \\
\hline Seattle & 21.1 & 14.6 & 8.1 \\
\hline Washington, DC & 11.8 & 8.5 & 5.2 \\
\hline All Educated & 14.3 & 10.9 & 8.7 \\
\hline \multicolumn{4}{|l|}{ Balanced } \\
\hline Bridgeport & 10.8 & 6.9 & 4.7 \\
\hline Chicago & 17.2 & 12.7 & 9.8 \\
\hline Hartford & 9.0 & 8.9 & 7.8 \\
\hline New York & 15.6 & 13.8 & 9.4 \\
\hline Portland & 20.2 & 14.2 & 9.7 \\
\hline Providence & 19.5 & 15.4 & 8.9 \\
\hline Sacramento & 20.2 & 13.7 & 8.9 \\
\hline Tampa & 12.2 & 12.0 & 9.3 \\
\hline All Balanced & 16.1 & 13.3 & 9.3 \\
\hline
\end{tabular}

Source: Authors' calculations using the 2000 IPUMS and 2005 ACS.

Note: Immigrant populations include children of immigrants. See text for details.

Averages are population weighted.

Corresponds to Figure 14 
Appendix Table 13

Public Assistance Rates

\begin{tabular}{|c|c|c|c|}
\hline $\begin{array}{l}\text { Metrotype/ } \\
\text { Metropolitan Area }\end{array}$ & Recent Immigrants & All Immigrants & Natives \\
\hline Full U.S. 2007 & 0.6 & 0.8 & 1.0 \\
\hline 42 Metros 2007 & 0.6 & 0.8 & 1.0 \\
\hline Full U.S. 2000 & 1.6 & 1.7 & 1.5 \\
\hline \multicolumn{4}{|l|}{ New } \\
\hline Atlanta & 0.1 & 0.2 & 0.5 \\
\hline Austin & 0.3 & 0.3 & 0.4 \\
\hline Charlotte & 0.6 & 0.6 & 0.5 \\
\hline Dallas & 0.3 & 0.3 & 0.5 \\
\hline Denver & 0.5 & 0.7 & 0.8 \\
\hline Minneapolis & 3.1 & 2.9 & 1.2 \\
\hline Orlando & 0.1 & 0.5 & 0.6 \\
\hline Phoenix & 0.3 & 0.6 & 0.7 \\
\hline Raleigh-Durham & 0.2 & 0.2 & 0.6 \\
\hline Salt Lake City & 0.7 & 0.6 & 0.6 \\
\hline All New & 0.5 & 0.6 & 0.6 \\
\hline \multicolumn{4}{|l|}{ Hispanic } \\
\hline Bakersfield & 1.3 & 1.6 & 2.2 \\
\hline El Paso & 0.1 & 0.7 & 0.5 \\
\hline Fresno & 2.0 & 2.4 & 2.6 \\
\hline Houston & 0.1 & 0.3 & 0.5 \\
\hline Las Vegas & 0.1 & 0.4 & 1.0 \\
\hline Los Angeles & 0.8 & 1.0 & 1.2 \\
\hline McAllen & 1.9 & 1.4 & 0.5 \\
\hline Miami & 0.4 & 0.5 & 0.5 \\
\hline Oxnard & 0.6 & 1.0 & 0.7 \\
\hline Riverside & 0.7 & 0.6 & 1.2 \\
\hline Salinas & 0.6 & 0.6 & 1.0 \\
\hline San Antonio & 0.2 & 0.4 & 0.6 \\
\hline San Diego & 0.5 & 1.0 & 0.8 \\
\hline Stockton & 1.3 & 1.1 & 1.6 \\
\hline Tucscon & 0.2 & 0.4 & 1.3 \\
\hline Visalia & 1.4 & 1.8 & 2.9 \\
\hline All Hispanic & 0.6 & 0.8 & 1.0 \\
\hline \multicolumn{4}{|l|}{ Educated } \\
\hline Baltimore & 0.0 & 0.2 & 0.9 \\
\hline Boston & 0.8 & 1.0 & 0.9 \\
\hline Detroit & 0.4 & 0.9 & 1.5 \\
\hline Philadelphia & 0.8 & 1.4 & 1.4 \\
\hline San Francisco & 0.8 & 0.8 & 1.1 \\
\hline San Jose & 0.9 & 0.9 & 0.9 \\
\hline Seattle & 1.5 & 1.6 & 1.2 \\
\hline Washington, DC & 0.4 & 0.6 & 0.6 \\
\hline All Educated & 0.7 & 0.9 & 1.1 \\
\hline \multicolumn{4}{|l|}{ Balanced } \\
\hline Bridgeport & 0.3 & 0.6 & 1.6 \\
\hline Chicago & 0.4 & 0.5 & 1.1 \\
\hline Hartford & 0.3 & 0.9 & 1.5 \\
\hline New York & 0.7 & 0.9 & 1.3 \\
\hline Portland & 1.5 & 1.3 & 1.2 \\
\hline Providence & 1.1 & 1.3 & 1.1 \\
\hline Sacramento & 1.8 & 1.6 & 1.6 \\
\hline Tampa & 0.2 & 0.4 & 0.8 \\
\hline All Balanced & 0.7 & 0.9 & 1.2 \\
\hline
\end{tabular}

Source: Authors' calculations using the 2000 IPUMS and 2005 ACS.

Note: Immigrant populations include children of immigrants. See text for details.

Public Assistance is defined as receiving GA or TANF. Averages are population weighted.

Corresponds to Figure 15. 